\title{
Total Economic Valuation of the National Park Service Lands and Programs: Results of a Survey of The American Public Faculty Research Working Paper Series
}

\author{
Michelle Haefele \\ Colorado State University \\ John Loomis \\ Colorado State University \\ Linda J. Bilmes \\ Harvard Kennedy School
}

\section{J une 2016 \\ RWP16-024}

Visit the HKS Faculty Research Working Paper Series at:

https://research.hks. harvard.edu/publications/workingpapers/Index.aspx

The views expressed in the HKS Faculty Research Working Paper Series are those of the author(s) and do not necessarily reflect those of the John F. Kennedy School of Government or of Harvard University. Faculty Research Working Papers have not undergone formal review and approval. Such papers are included in this series to elicit feedback and to encourage debate on important public policy challenges. Copyright belongs to the author(s). Papers may be downloaded for personal use only. 


\section{Contents}

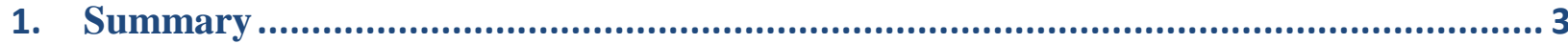

2. Introduction .................................................................................................. 4

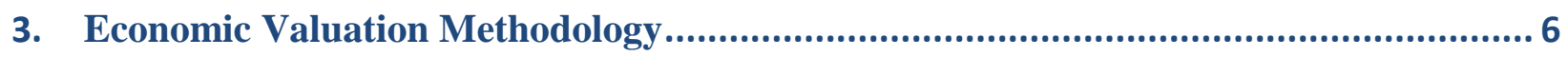

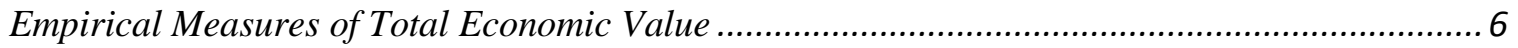

Empirical Methods Used For this Study ............................................................................ 7

4. Questionnaire Design and Survey Implementation ................................................ 9

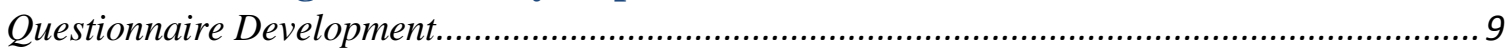

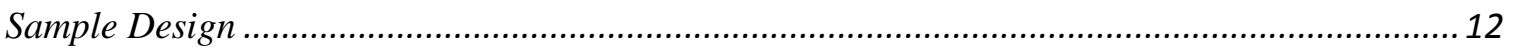

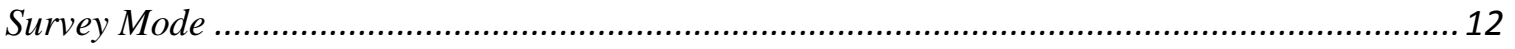

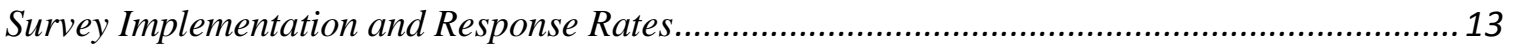

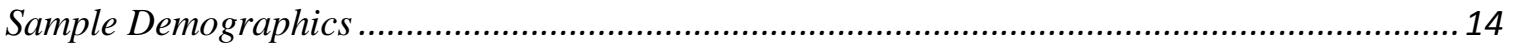

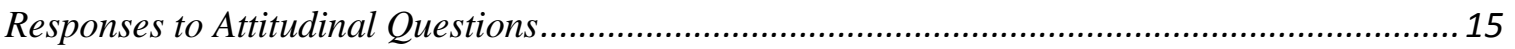

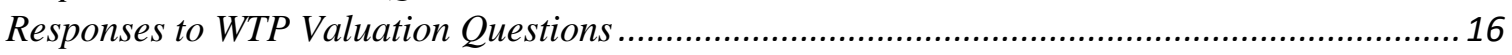

5. Statistical Analyses and Results......................................................... 18

6. Estimates of Economic Value for National Parks and NPS Programs...................... 21

Calculating National Total Economic Value of National Parks and NPS Programs...................24

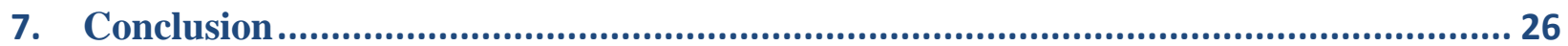

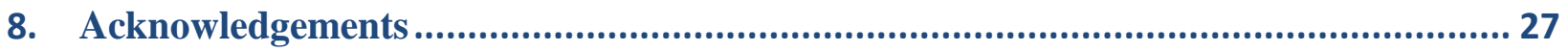

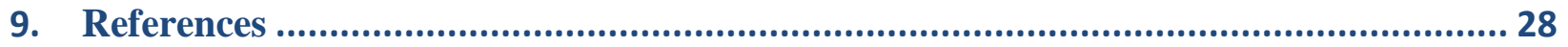

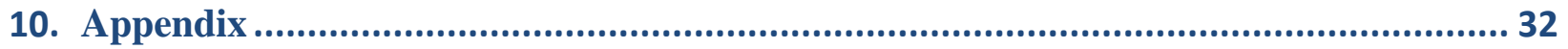

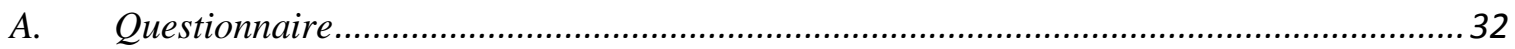

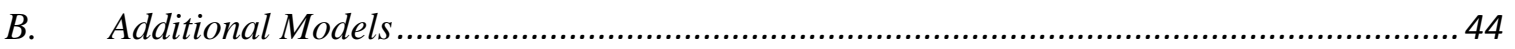

C. Detailed Breakdown of Respondents' Reasons for Zero Bids.......................................... 48 


\section{Summary}

This paper presents the first-ever comprehensive estimate of the total economic value of the National Parks Service. The estimate covers administered lands, waters, and historic sites as well as NPS programs, which include protection of natural landmarks and historic sites, partnerships with local communities, recreational activities and educational programs.

Our estimate of the total economic value to the American public is $\$ 92$ billion. Two-thirds of this total ( $\$ 62$ billion) is for National Park lands, waters and historic sites; the remaining $\$ 30$ billion is attributed to NPS Programs. The estimate, which is based on very conservative assumptions, includes not only the value attributed by visitors to the parks, but also a significant "non-use" or "existence" value. This is the value derived by the public from simply knowing that NPS assets are protected for current and future generations, regardless of whether or not they actually choose to visit.

Our results are derived from a survey of a sample of U.S. households conducted for this study. Participants were asked whether they would be willing to pay specific amounts in increased annual federal income taxes over a ten-year period in order to retain the current National Parks and NPS Programs. This methodology is consistent with the techniques employed by numerous Federal agencies for economic valuation. The results reflect rational economic behavior-the higher the dollar amount in increased taxation, the less likely respondents were to pay. This indicates respondents were paying close attention to the payment amounts and gives us high confidence in our economic valuation.

Overall, nearly $95 \%$ of responding households indicated that protecting National Parks, including historic sites, for current and future generations was important to them. This was largely independent of visitation; $85 \%$ of respondents felt that they personally benefitted from National Parks, regardless of whether they visited the parks or not.

This paper describes our methodology in detail, including survey development techniques and implementation, as well as our statistical analysis. The paper also considers the policy implications of this first-ever analysis of NPS value.

The study was conducted independently of the National Park Service. The research was funded through the generosity of the S.D. Bechtel Jr. Foundation, the Turner Foundation, Cody J. Smith of the Summit Foundation, the National Park Foundation and UPD Consulting Inc., and under the auspices of Colorado State University and Harvard University. 


\section{Introduction}

The National Park Service (NPS) is an agency of the U.S. Department of the Interior founded in 1916. It oversees the system of National Park lands (national parks, national monuments, national recreation areas, national historic sites, and other units (hereafter National Parks), as well as numerous programs both within the parks and in communities throughout the country. ${ }^{1}$

This paper presents the first-ever estimate of the total economic value of the entire National Park system and NPS programs, including both direct and passive use values. ${ }^{2}$ Direct use values derive from on-site use, whereas passive use values are independent of on-site use. In each case we use survey data to calculate "net economic values"- how much people would pay over and above what they currently spend in order to enjoy National Parks and NPS programs. For non-visitors, these net economic values reflect the entire benefit.

Over the past 30 years a number of studies have looked at the amount the public would pay for individual units or specific benefits of the NPS system. These studies utilize a range of attributes, values and methodologies ${ }^{3}$. Other studies focus on the direct economic impact of visitor spending at National Parks in terms of jobs created or incremental tax revenues generated. ${ }^{4}$

The present study is the first to look at the NPS system as a whole. It addresses the broader question of the overall economic value to the American public (not only visitors, but also non-visiting households) ${ }^{5}$. The concept of passive use value was articulated by Krutilla (1967) as "... when the existence of a grand scenic wonder or a unique fragile ecosystem is involved, its preservation and continued availability are a significant part of the real income of many individuals." ${ }^{\circ}$ Put another way, passive use values are the values people have which are "... independent of any present or future use these people might make of those resources."

\footnotetext{
1 The NPS participates in numerous "cooperative programming" activities, in which the agency works together with local, state and other federal jurisdictions, NGOs and other stakeholders and interested parties to achieve its larger mission of promoting stewardship and recreation.

${ }^{2}$ Choi and Marlowe (2012) outlined a framework for such an analysis, in which they established a baseline methodology for valuing the NPS which they applied to a case study for Joshua Tree National Park. The paper won the Christopher P. Kaneb Prize for the Best Masters Student Paper awarded by The Harvard Environmental Economics Program.

${ }^{3}$ Previous analysis of NPS visitation data using a travel demand method found a median value of $\$ 108$ per day (Neher, et al. 2013). Two other studies also used the travel demand method. Kerkvleit et al. (2002) applied the travel demand method to estimate the economic value of sport fishing in the Greater Yellowstone area (including within Yellowstone National Park). Heberling and Templeton (2009) estimated the value of recreation at Great Sand Dunes National Park in Colorado. Leggett et al. (2003) estimated the additional amount a household would pay to visit Fort Sumter National Monument in South Carolina. Douglass and Harpman (2004) used the contingent valuation method to assess the value of recreation at Lake Powell and the Glen Canyon National Recreation Area. Duffield (2006) estimates both use and non-use values for National Park System sites within the Colorado River Watershed. Schulze et al. $(1983,1985)$ used contingent valuation to estimate the value of air quality (visibility) in the National Parks in the Southwest (Grand Canyon NP, Mesa Verde NP and Zion NP). Welsh et al. (1997) estimated the passive use values associated with differing levels of water flow in the Grand Canyon National Park. Turner and Willmarth (2014) used a choice experiment to estimate both use and non-use values for resources within North Cascades National Park.

${ }^{4}$ See Thomas, Huber and Koontz, 2014 for the most recent National Park visitor spending effects.

${ }^{5}$ The study is part of a larger project whose goal is a complete economic assessment of the National Park Service, including ecosystem services, education, intellectual property and cooperative programming. See Carbon Sequestration in the U.S. National Parks: A Value Beyond Visitation, HKS Working Paper No. RWP15-007 (Banasiak, Bilmes and Loomis, 2015) and other papers in the series (forthcoming).

${ }^{6}$ Krutilla, 1967, p779

${ }^{7}$ Freeman 2003, p. 137
} 
Passive use values include existence value and bequest value. Existence value is the utility or benefit that accrues to an individual from simply knowing that a resource (such as a National Park) exists, even if the individual never expects to visit or see or otherwise use the resource. Bequest value measures the benefit or utility an individual enjoys from knowing that a resource will be preserved for future generations.

Our study began with work by Choi and Marlowe (2012) that outlined a comprehensive framework for valuing the NPS, including economic impacts, intangible benefits from cooperative programs and nonmarket value.

While it is impossible to fully capture the value of priceless assets such as the iconic scenery and ecosystems protected in the National Parks, we have used an approach that measures what the American public would pay to avoid being deprived of these assets. Therefore this study is almost certainly a substantial under-valuation.

Additionally, we deliberately selected a highly conservative methodology and used conservative assumptions in conducting the survey ${ }^{8}$. For example, we attributed a zero value to all those who did not return the survey form - even though there are many reasons why people do not participate in surveys. ${ }^{9}$ We used a conservative method for weighting responses and for estimating respondents' economic values. In every step of the methodology we erred heavily on the side of conservatism.

Thus we believe that the $\$ 92$ billion in NPS economic value that we present should be viewed as the very minimum value that the American public places on the National Park Service system and programs.

\footnotetext{
${ }^{8}$ See section 6 for a discussion of the conservatism of our approach.

${ }^{9}$ We conducted a brief follow-up phone interview of a small subset of non-respondents to ascertain why they did not return the survey. These results confirm that non-response was primarily due to a reluctance to answer any survey rather than a negative perception of the National Park Service. Most did not answer the phone at all, $14 \%$ of those who did answer refused to participate in the three-question survey. Of the original non-respondents who agreed to participate in the follow-up, $79 \%$ indicated that they do not participate in long surveys.
} 


\section{Economic Valuation Methodology}

\section{Empirical Measures of Total Economic Value}

Most of the economic value associated with the National Park Service is what economists call non-market value. There are no formal markets for such things as public lands recreation opportunities, clean air and threatened and endangered species so there are no market clearing "prices" for these goods as there are for traded goods such as food or clothes. At the broadest level, it is impossible to estimate the full value of protecting vital ecosystems and lands.

However, it is still important to determine at least a partial value for such protections, whose worth is vastly under-estimated by standard accounting and budgetary methods. Economic techniques are helpful in filling this gap. Economic values (including direct use and passive use values) are typically defined by economists as the maximum amount that an individual would pay rather than do without an increase in a particular good or service. This definition is referred to as "willingness to pay" (WTP) and is the federally approved measure of value used in cost-benefit analyses by a wide range of federal agencies including the and U.S. Bureau of Reclamation (Welsh, et al. 1997; U.S. Water Resources Council 1983), U.S. Office of Management and Budget (1992), National Oceanic and Atmospheric Administration (Arrow et al. 1993), and U.S. Environmental Protection Agency (2010). WTP would clearly be the most appropriate value to estimate if additions to the National Park System and new programs were being proposed. However, given the overall budget situation facing the U.S. today, it was viewed by potential respondents as unrealistic to anticipate any significant additions to the National Park System over the next decade. Rather it is it was viewed as more likely there would be cuts to National Parks and NPS Programs, therefore the survey was based on this premise. ${ }^{10}$

When estimating the value associated with taking away a resource that the public already "owns" or is entitled to, economists generally use the concept of minimum "willingness to accept" (WTA) (Freeman, 2003). This is the minimum payment a person would accept in exchange for a one-unit decrease in a particular good or service. In a review of the literature on reported WTP and WTA, Horowitz and McConnell (2002) found that WTA was frequently twice as large as WTP for all types of goods, and as much as 10 times larger for non-market goods. Several explanations for this effect have been offered. These include the binding budget constraint that applies to WTP but not to WTA. As Freeman summarizes "These differences (between WTP and WTA) can be explained by the absence of close substitutes in the case of unique and perhaps irreplaceable resources..." ${ }^{11}$ Hanemann (1991) also showed that if a person does not think there are good substitutes for the natural resource that could be bought for the money provided as compensation for giving up the natural resource, WTA could be larger than WTP by a sizeable amount. This is certainly applicable to the valuation of National Parks - given the uniqueness of many National Parks we would expect WTA to be substantially higher than WTP.

Given that the goal of the present study is to estimate the total economic value of all existing National Parks that the public already "owns" and has a legal right to, WTA would be the theoretically correct approach to estimating total economic value. However, economists have had limited success empirically estimating WTA in non-market valuation surveys. This may be due in part to the fact that it is rare for people to be asked if they are willing to give up an existing public resource in exchange for some amount of money (perhaps in the form of a tax refund). It is much more common, and therefore more familiar, for

\footnotetext{
${ }^{10}$ During focus groups conducted to help formulate the survey instrument, participants said that they believed it was unlikely that the federal government would be able to add significantly to the National Parks Service holdings over the next decade, given the budget constraints facing the US. They did, however, view it as realistic that there might be cuts to the system. This discussion was independent of whether or not they believed it was desirable to expand the system. The focus groups are described in more detail below.

${ }^{11}$ Freeman 2003, p. 87
} 
questionnaires to ask households if they would pay additional taxes of some form (sales, property, income) to provide more of a public good such as expanding schools, parks, open space, roadways, etc. It may be that the public has more experience with and therefore may find it more credible to be asked to pay rather than to accept payment. Thus, like most economists, we have used willingness to pay to retain the current amount of National Parks and NPS programs. This almost certainly generates results that are an underestimate of the true economic value of the entire the National Park System and NPS Programs.

\section{Empirical Methods Used For this Study}

As noted above, the majority of the economic value associated with National Parks and NPS programs is non-market value, which needs to be measured using techniques that do not rely on market prices. This can be done either indirectly or directly. Indirect measures of non-market values infer the value of the good in question by observing consumer behavior. For example, a common method to estimate recreation values $^{12}$ uses the estimated cost of a visit (direct expenses plus the value of travel time) as a price along with the quantity of trips taken to trace out a demand curve, from which the value of the recreation experience can be calculated (Champ et al. 2003).

Direct methods to measure non-market values are also referred to as "stated preference," because such techniques involve directly asking survey respondents what they would pay for their preferred alternative. ${ }^{13}$ Stated preference methods are the only methods which can estimate passive use values (Freeman, 2003) because people who have passive use values for a resource, such as existence and bequest values, rarely manifest these values in any traceable behavior. The two main types of stated preference methods are contingent valuation (CVM) and choice experiments (CE, also sometimes called contingent choice, conjoint method, or stated choice).

Contingent valuation (CVM) is a method whereby survey respondents are asked to indicate their willingness to pay for a non-market good like a recreation experience or passive use values such as existence value, option value or bequest value (Mitchell and Carson 1989). The choice experiment (CE) method is a stated preference method wherein survey respondents are asked to choose from a set of alternative scenarios which vary in the level of several attributes, one of which is the price or cost associated with each (Louviere et al. 2000, Bennett and Blamey 2001).

Boyle and Markowski (2003) and Turner (2012) both recommend using choice experiments when estimating economic values for National Park Service resources. Both also describe a comprehensive framework for developing estimates of value for National Park System resources and National Park Programs.

In addition, the choice experiment has several practical advantages over CVM. It is capable of gathering more information from survey respondents. Researchers can offer respondents more than the "take it or leave it" option of a CVM study, enabling respondents to choose their most preferred from a set of options or alternatives or to rank the options (Freeman 2003). The options contain differing levels of attributes, including a monetary attribute (the "price" of the option). The exercise presented to survey respondents most closely mimics the act of purchasing a market good, where consumers choose from among several options of a particular good such as a car, weighing the various models' attributes (one of which is the cost) in order to determine the most preferred (Louviere et al. 2000, Freeman 2003, Hensher et al. 2005).

\footnotetext{
${ }^{12}$ Commonly known as the travel cost or travel demand method

${ }^{13}$ Stated preference methods were originally used to estimate recreation use value. Recreation use values can also be estimated with the actual behavior based methods called revealed preference methods. An example of a revealed preference method is the travel cost demand method of recreation behavior where visitors purchase gasoline and make observable recreation trips. However, revealed preference methods are incapable themselves to estimate passive use values since there is no observable behavior with passive use values. For a listing of recreation values see Loomis, 2005.
} 
In addition, when analyzing the results of choice experiments, researchers are able to estimate the incremental willingness to pay (the economic value) for each of the non-monetary attributes of the preferred alternative (Freeman 2003). This is beneficial in our case in determining the overall value of National Park Service programs and units as well as determining which attributes of those programs and units are most valuable to the public.

Based on the recommendations and on the advantages of the choice experiment format for valuing the many different dimensions of the National Park System, the choice experiment method was selected as the most appropriate method to apply for our study. 


\section{Questionnaire Design and Survey Implementation}

This section describes the steps used to develop and refine the questionnaire and the survey implementation process.

\section{Questionnaire Development}

Given the scale and complexity of the public good being valued, we believed it was essential to solicit input from potential respondents in order to ensure that our questionnaire design was clear and the questions phrased in clear, unambiguous language. The initial survey design was thus refined over several months with the aid of nine focus groups and six individual interviews conducted in Fort Collins and Denver, Colorado, Woburn, Massachusetts and South San Francisco, California. The focus groups each included about a dozen people randomly selected as representative of the general population. They were told that the purpose of the focus group was to help design a survey. A page of the survey was handed out and participants were asked to read it, mark up anything that was not clear, and answer the questions on the page. The moderator then went around the room and asked participants to explain their concerns with the text or the questions. This process was repeated for each page of the survey. The focus groups usually met for about two hours. We ran separate focus groups for the National Park units and for National Park programs so that adequate time was available to discuss each aspect of the survey in detail.

The input from these focus groups was extremely helpful in designing a survey that was clear to the general public and contained plausible scenarios regarding the budgetary issues facing National Park units and Programs and how these might be addressed. The focus group comments also resulted in a decision to design a single long (12 page) survey that included both National Park units and Programs.

The final questionnaire included questions on the National Park units and NPS programs. (see the Appendix for a copy of the full questionnaire). The first section contained a brief description of the National Park Service with examples of the various types of National Parks and NPS programs. National Parks were divided into three broad categories: (i) National Parks that focus on the preservation of nature and nature-based recreation, (ii) Parks that focus on the preservation of American history and culture or the commemoration and remembrance of significant events and people and (iii) Parks that focus on protecting shorelines and bodies of water. For nature-focused and water-focused parks we used acres as the unit of measure, but for the historic parks we used the number of sites. The reason for this is that the history-focused parks are often very small, representing less than $1 \%$ of the total NPS acreage, but account for $57 \%$ of total NPS units.

NPS programs were consolidated into four main focus areas: (i) Programs that focus on the preservation of local historic buildings and sites; (ii) Programs that create and improve recreation opportunities for communities; (iii) Programs that focus on the protection of natural environments and features that are important to communities and (iv) Educational Programs that help children and adults learn about historical, cultural and environmental topics. ${ }^{14}$ Each of these is described in terms of annual outputs. Tables 1a and $1 \mathrm{~b}$ below show the Park and Program attributes respectively along with the specific metrics used for each (the full descriptions can be found in the example questionnaire in the Appendix). In the questionnaire these divisions are denoted using icons and colors that are carried through the questionnaire.

\footnotetext{
${ }^{14}$ NPS administers a wide range of programs. For the purposes of this survey, we focus on four major programmatic areas: conservation, education, historical preservation, and recreation.
} 
Table 1a. Attribute Descriptions - National Parks

\begin{tabular}{|c|c|}
\hline Types of National Parks & Metric \\
\hline $\begin{array}{l}\text { National Park areas that focus on the preservation of nature and nature-based recreation } \\
\text { (e. g. National Parks, some National Monuments, National Preserves, National Parkways, } \\
\text { National Scenic Trails and some National Recreation Areas). }\end{array}$ & $\begin{array}{l}\text { Acres: } \\
79,096,632\end{array}$ \\
\hline $\begin{array}{l}\text { National Park areas that focus on the preservation of American history and culture or the } \\
\text { commemoration and remembrance of significant events and people (e. g. National } \\
\text { Historic Sites, National Battlefields, National Memorials and some National Monuments). }\end{array}$ & $\begin{array}{l}\text { Park units: } \\
226\end{array}$ \\
\hline $\begin{array}{l}\text { National Park areas that focus on protecting shorelines and bodies of water (e. g. National } \\
\text { Lakeshores on the Great Lakes, National Seashores, National Rivers and some National } \\
\text { Recreation Areas). }\end{array}$ & $\begin{array}{l}\text { Acres: } \\
4,818,275\end{array}$ \\
\hline
\end{tabular}

Park acreage, number of sites and program outputs are all from various National Park Service publications or personal communication with NPS from 2012 to 2013.

Table 1b. Attribute Descriptions - National Park Service Programs Outside of National Parks

\begin{tabular}{ll}
\hline Types of NPS Programs & Metric \\
\hline $\begin{array}{l}\text { Preservation of local historic buildings and sites which commemorate } \\
\text { American history and culture or significant events and people. }\end{array}$ & $\begin{array}{l}\text { Annual number of historic } \\
\text { sites protected: } 2,000\end{array}$ \\
Creation and improvement of recreation opportunities for communities. & $\begin{array}{l}\text { Annual number of acres } \\
\text { transferred: } 2,700\end{array}$ \\
Protection of natural environments and features which are important to & $\begin{array}{l}\text { Annual number of sites } \\
\text { designated: } 114\end{array}$ \\
communities. & Children attending programs \\
Educational programs which help children and adults learn about & annually: 4,100,000 \\
historical, cultural and environmental topic. &
\end{tabular}

Acreage, number of sites and program outputs were based on National Park Service publications and/or personal communication with NPS personnel from 2012 to 2013. Children attending educational programs was calculated based on the 2012 NPS estimate and materials prepared by Dr. Milton Chen, Edutopia, February 2013.

The second section of the questionnaire consisted of twelve Likert-scale style questions designed to elicit respondents' general attitude toward the NPS, National Parks, and outcomes of the NPS programs. This was followed by a detailed description of the National Parks and NPS programs and the valuation questions. Focus group feedback indicated that valuing a hypothetical major increase in either National Parks or NPS programs was viewed as unrealistic. Thus the scenario we presented to respondents was a proposal to sell some National Park lands and cut some NPS programs as a response to budget shortfalls. This was credible to respondents and has some validity as there are occasional political proposals along these lines.

In order to minimize the potential for hypothetical bias (where respondents indicate a higher willingness to pay than they would actually pay in cash), the description above was followed by a caution which asked respondents to consider their budget as well as the combined cost of both proposals when choosing their preferred options. This technique is based on the work of several researchers (Cummings and Taylor 1999, Carlsson et al. 2005, Silva et al. 2011) and has been shown to help reduce the tendency for respondents to overstate their willingness to pay.

Respondents were presented with two choice questions, one on National Parks the other on NPS programs. The park and program categories described above were used as the non-price attributes (three for parks, four for programs). The choice questions each consist of three options. The status-quo (or "do nothing") option proposes the highest levels of cuts, with a tax cost of $\$ 0$. The middle option proposes 
smaller cuts and some annual tax cost. The third option for each choice question preserves all current parks or programs with the highest annual cost to the household.

We chose an annual increase in federal income taxes as a realistic means of payment to prevent the sale of National Parks or to avoid cuts to NPS programs. While taxes may obtain "protest" responses, where a survey respondent rejects the payment due to something other than a true zero valuation of the good (e.g. attitudes toward the federal government in general or objections to paying by means of taxes), this type of payment vehicle has desirable consequentiality properties that aid in obtaining valid willingness to pay responses (Carson and Groves, 2007). To check for protests, each choice question included a follow-up question asking for the reason where the willingness to pay was indicated at zero.

The final overall survey design consisted of 16 versions of the questionnaire. ${ }^{15}$ Each version varied the percentage of cuts to National Parks and NPS Programs, and varied the amount of the associated increase in income taxes the respondent would be asked to pay. ${ }^{16}$ The levels of those values are shown in Table 2. Note that the options with the maximum sale of National Parks and maximum cuts to NPS programs (described in the survey as the status quo) vary only in the level of cuts, and the price is always zero. The options with no sale of National Parks and no cuts to NPS programs is the highest price option and vary only in the household cost (the percentage of land sold or cuts to programs is always zero).

Table 2. Choice Question Attribute Levels

\begin{tabular}{lll}
\hline & $\begin{array}{l}\text { Non-Price Attribute levels } \\
\text { Cuts to programs or sale of } \\
\text { parks }\end{array}$ & $\begin{array}{l}\text { Price levels/Income Tax Cost } \\
\text { Household's annual federal } \\
\text { income tax cost for each of the } \\
\text { next 10 years }\end{array}$ \\
\hline $\begin{array}{l}\text { Option } \\
\text { Maximum sale of National } \\
\begin{array}{l}\text { Parks / maximum cuts to NPS } \\
\text { programs }\end{array}\end{array}$ & $\$ 0 \%, 25 \%, 30 \%, 40 \%$ & $\$ 15, \$ 25, \$ 35, \$ 50, \$ 60, \$ 75, \$ 90$, \\
\hline $\begin{array}{l}\text { Smaller sales of some or all } \\
\text { National Parks / smaller cuts to } \\
\text { some or all NPS programs }\end{array}$ & $0 \%, 5 \%, 10 \%, 20 \%$ & $\$ 100$ \\
\hline $\begin{array}{l}\text { No sale of National Parks / no } \\
\text { cuts to NPS programs }\end{array}$ & $0 \%$ & $\$ 115, \$ 150, \$ 200, \$ 250, \$ 300$, \\
\hline
\end{tabular}

Each of the choice questions followed the same format, which incorporated the icons and color codes used in the description of National Parks and NPS program types (the option attributes) along with colorcoded pie charts graphically illustrating the reductions (sale of National Parks or cuts to annual NPS program outputs). Respondents were asked to first indicate their most preferred option, then their least preferred option.

The valuation section concluded with two questions designed to elicit respondents' perspectives on the consequentiality of the questionnaire (Carson and Groves 2007, Vossler and Evans 2009). One asked respondents how certain they were that their answers would be used to make policy decisions. The second asked how certain they were that they would actually have to pay the proposed tax. ${ }^{17}$ Respondents giving zero WTP were asked the reason for this valuation.

\footnotetext{
15 The full design is available from the authors upon request

${ }^{16}$ Barbara Kanninen of BK Econometrics guided the design of the 16 versions.

${ }^{17}$ Some focus group participants expressed worry that that the government would use responses to their surveys to decide whether and how much to reduce National Parks - showing that they did take the process seriously.
} 


\section{Sample Design}

This section discusses the overall sample design, including sources of potential problems and ways of mitigating them.

The first decision point in determining the survey sample design is to identify the affected populationthe group to which the benefits and/or costs of the good being valued accrue. This is most straightforward when the population that will benefit is the same as the population that will pay for the good in question. In the case of the total economic value of the NPS, this population is all U.S. households.

The next step is to devise a sampling frame that ensures the sample is representative of the affected population. In order for the results of the valuation survey to be generalizable to the entire population, the sample must be unbiased - that is every member of the affected population (in this case all U.S. households) must have an equal probability of being selected for the sample (Mitchell and Carson 1989). The extent to which the sample is unbiased will depend upon the method of generating the sample (which to some extent will depend upon the survey mode, discussed below).

Using households listed in telephone directories (for either phone or mail surveys) is a common method of generating a national household sample. However such a sample could potentially be biased for excluding households without landline telephones (an increasingly common situation due to the prevalence of cellular phones) as well as households with unlisted telephone numbers. Random digit dialing (RDD) of area codes and both landline and cell phone prefixes provides reasonably good coverage of the U.S. population. RDD has become commonplace among most university survey research centers and private survey sampling companies.

Internet panel surveys require access to the internet. Some survey research firms overcome this problem by providing potential panel members with computers and internet connections. Such panels have the potential to result in self-selection bias (since they exclude households whose members are unwilling to participate in internet surveys).

To avoid these sampling problems, survey researchers are increasingly turning to address-based samples. Our sampling frame consists of all U.S. households with valid addresses contained in the U.S. Postal Service Delivery Sequence file. According to the Wyoming Survey and Analysis Center, "This is the sampling frame that is recognized to provide the best coverage of all households in a geographic area of interest at reasonable cost." The Center calculated that random samples yielding 600 completed surveys "...will yield margins of error of about \pm 4 percentage points, with $95 \%$ confidence." 18

\section{Survey Mode}

Survey mode refers to the means by which the survey questionnaire is delivered to potential respondents. Modes include mailed questionnaires, phone surveys, a combination of telephone and mail and, more recently, the Internet. Some survey modes, such as in-person surveys, may produce higher willingness to pay values due to respondents wishing to please the interviewer (Leggett et al. 2003).

Recent research has indicated that a mixed mode approach (combining online, mail and/or phone) may increase response rates and the representativeness of the final sample (Grandjean et al. 2009, Taylor et al. 2009, Poole and Loomis 2010, Kaplowitz et al. 2004, Evans and Mathur 2005, Lindhjem and Navrud 2011, Berrens et al. 2004). Hence in our survey we used a mixed internet-mail mode.

\footnotetext{
${ }^{18}$ Wyoming Survey and Analysis Center (2013).
} 


\section{Survey Implementation and Response Rates}

Our report presents the results of two separate rounds of surveying done in 2013-14 and 2015. The procedures followed for the two survey rounds were nearly identical. All members of the survey sample were initially invited to participate in the survey by means of a paper letter on letterhead with both Colorado State University and the University of Wyoming mailed to their home address. The letter provided a web link to the survey in the form of a unique URL. A few weeks later, non-respondents in both rounds were mailed a second paper letter which repeated their survey web link, but also included the 12-page color paper questionnaire (with a postage paid return envelope) and a two-dollar bill as an incentive/reward.

In the first round (2013-14), non-respondents for whom phone numbers were available were contacted by phone with a reminder message. A third reminder letter with a web link was sent a few days later. The final contact in the first round included a second paper questionnaire and web link mailed to nonrespondents. In the second round (2015), non-respondents were sent a reminder postcard about two weeks after the first paper questionnaire was mailed. Then two waves of phone calls were made-one immediately after the reminder postcard and the second after a second paper survey was mailed about a month later. Details of the survey processes are shown in Table 3.

Table 3. Survey Procedures for Two Survey Rounds

Round 1: 2013-14 Round 2: 2015

Initial paper letter describing the survey, with unique web link for online response

late Nov 2013 late April 2015

\begin{tabular}{lcc}
\hline Second letter with paper questionnaire and web link & early Dec 2013 & mid-May 2015 \\
\hline Reminder postcard & N.A. & late-May 2015 \\
\hline Reminder phone calls & mid-Dec 2013 & $\begin{array}{c}\text { late-May and } \\
\text { late-June 2015 }\end{array}$ \\
\hline Reminder letter with web link & late-Dec 2013 & N.A. \\
\hline Reminder letter with replacement paper questionnaire and web link & late-Jan 2014 & mid-June 2015 \\
\hline
\end{tabular}

The 2013-14 sample included 1,630 valid addresses with 317 questionnaires completed (for a 19\% response rate). The 2015 sample included 2,246 valid addresses and 391 completed questionnaires (17\% response rate). We pooled the data from the two survey rounds after determining that the samples were not statistically different from each other. The results reported in the remainder of this paper reflect the pooled sample. The pooled sample has about 700 observations, well over the minimum sample size of 500 that is recommended for conjoint/choice experiment (Orme, 2010).

The overall response rate was $18 \%$. While this is lower than we would have liked, we should note the National Research Council (NRC) has documented the general decline in survey response rates over the last decade (2013). ${ }^{19}$ Even some official U.S. Census Bureau of surveys of the general public are in the

\footnotetext{
${ }^{19}$ Our response rate is similar to other stated preference survey response rates. For example, the recent Elwha River restoration study had a response rate of $24 \%$ (Stratus Consulting, 2015), compared with response rates in earlier Elwha studies of $68 \%$ for the state of Washington and 55\% from the rest of the U.S. (Loomis, 1996). Two main factors contributed to the low response rate. The first is the target population. National surveys of the general public tend to have the lowest response rates. State specific surveys of the general state population often have higher response rates, and community surveys (specific to a particular community and on particularly relevant topics) generally have the highest response rates. In addition, longer surveys have lower response rates, dropping off steeply as surveys reach 8 pages and again when they reach 12 pages. Our response rate of $18 \%$ is comparable to several recent surveys conducted by the Wyoming Survey and Analysis Center. The most similar survey to ours, a 12-page survey of the general public in Utah on recreation resulted in a $20 \%$ response rate (Brian Harnisch, Wyoming Survey and Analysis Center, personal communication, 2016).
} 
range of $10 \%$ to $30 \%$ (NRC 2013). ${ }^{20}$ The NRC report suggests that ex-post survey weighting of the data may help to reduce risks associated with a low response rate. ${ }^{21}$ One of the weighting techniques they recommend that is widely used is "raking ratio adjustment" (page 3-4) because it can account for multiple variables that might differ somewhat between the sample and the population. Our use of the raking approach is discussed in Section 5 (Statistical Analyses and Results) below.

\section{Sample Demographics}

Only $27 \%$ of respondents chose the online survey mode; $73 \%$ returned the paper questionnaire. The raw sample is older, more highly educated and has a higher income than that of the United States as a whole, which would reduce the generalizability of the findings to the population as a whole (Table 4) if no statistical corrections are made. ${ }^{22}$ As explained below, we used statistical models to weight the sample so as to be representative of the U.S. population on key characteristics that influence economic valuation.

Table 4. Population and Sample Demographics

\begin{tabular}{lccccc}
\hline & $\begin{array}{c}\text { Median } \\
\text { Age }\end{array}$ & $\begin{array}{c}\text { Female }(\% \\
\text { over 15 years) }\end{array}$ & $\begin{array}{c}\text { Median HH } \\
\text { Income (\$) }\end{array}$ & $\begin{array}{c}\text { Bachelor's Degree } \\
\text { or More (\%) }\end{array}$ & Retired (\%) \\
\hline Survey sample & 57 & $53 \%$ & $62,500^{\mathrm{b}}$ & 51.13 & 39.7 \\
United States $^{a}$ & 37.3 & 51.6 & 52,250 & 18.73 & $16.2^{\mathrm{c}}$ \\
\hline
\end{tabular}

${ }^{a}$ Sources: U.S. Department of Commerce, Census Bureau, American Fact Finder (2012) and U.S. Social Security Administration.

b The sample median income falls within the range $\$ 50,000$ to $\$ 74,999$, the number reported here is the mid-point.

${ }^{\mathrm{c}}$ Based on 38,000,000 retirees as reported by the SSA and the U.S. population over the age of 18 .

Fifty-nine percent of survey respondents reported having visited a National Park in the last two years. This compares to an independent survey regarding visitation to National Parks that indicated $47 \%$ of the American public had visited a National Park (Taylor et al. 2011). Only 8\% of survey respondents indicated membership in environmental organizations.

As another check on the representativeness of our sample, we compared sample National Park visitation to the visitation levels reported in National Park Service annual reports. According to those reports, the average annual number of recreation visits for 2012-2015 was 283 million. Using our survey respondents' reported visitation frequency we calculated a weighted average per household annual visitation. Applying this to the total number of households in the U.S. and using the average household size, our data implies an annual visitation of 248 million, quite close to the average number of recreation visits reported by NPS.

\footnotetext{
${ }^{20}$ Public response rates for the US Decennial Census have fallen from $78 \%$ in 1970 to $63 \%$ in 2010, despite significant spending by the US Census Bureau on media advertising to increase the mail back rate.

${ }^{21}$ We conducted a follow-up survey of non-respondents to ascertain the reason for their non-response. The Wyoming Survey and Analysis Center (WYSAC) provided us with a list of non-respondents from the 2015 survey. We removed all those with disconnected phones, wrong numbers and phones that were not associated with a private household leaving a total of 438 numbers. Over the course of three days (June 14-17, 2016) 221 calls were made to a subset of the 438 eligible phone numbers. The responses provide some indication that most of the non-response was due to unwillingness to answer surveys (based on both the responses to the questions and on the high rate of refusal to participate in even a three question survey in this follow-up exercise), and did not suggest dislike of the National Parks. Half of those responding indicated that they had visited a National Park in the last two years; and $80 \%$ of those reached disagreed with the proposition that the U.S. government should sell off some National Parks. This provides us with confidence that we have been conservative in attributing a zero value to non-respondents.

${ }^{22}$ The descriptive statistics present the raw results from the survey. The weighted sample was used to determine the economic valuation values.
} 


\section{Responses to Attitudinal Questions}

Most respondents indicated support for National Parks and NPS programs, as indicated by the responses to the Likert scale questions (Table 5). These were the first questions following the survey introduction and the description of the various types of National Park areas and programs.

Table 5. Attitudes Toward the National Park Units and NPS Programs

\section{Statement}

\% of respondents

1. It is important to me that historic sites are protected for current and future generations whether I visit them or not. who agree ${ }^{a}$

2. National Park areas are good places to bring children to learn about nature.

$94.9 \%$

3. Local governments do not need any help from the National Park Service to protect local historic sites and buildings.

$96.2 \%$

4. I enjoy visiting historic sites and buildings.

$14.6 \%$

$89.8 \%$

5. The U.S. should sell off some National Parks.

$6.2 \%$

6. Local governments should be able to provide trails, parks and open spaces in communities without the help of the National Park Service.

$39.9 \%$

7. I enjoy using local trails, parks and open spaces in my community and in other places.

$86.6 \%$

8. I do not benefit directly from National Parks.

$14.7 \%$

9. Private businesses could probably do a better job than the federal government at protecting local historic sites and buildings.

$22.2 \%$

10. It is important to me that trails, parks, and open spaces in communities are protected for current and future generations, whether I use them or not.

$93.5 \%$

11. National Parks are important to me because I enjoy visiting them.

$80.8 \%$

12. It is important to me that National Parks are preserved for current and future generations whether I visit them or not.

$94.8 \%$

a Percentage of respondents indicating they either "agree" or "strongly agree" with the statement

The 2015 survey round included an additional question on respondents' political point of view (Table 6). It is interesting to note that the unweighted sample is generally somewhat politically conservative, but nonetheless supportive of protecting National Park lands, waters, and historic sites as well as NPS programs in general.

Table 6. How would you describe your overall political point of view?

\begin{tabular}{lr}
\hline Leaning Democratic & $9.21 \%$ \\
Mostly Democratic & $14.83 \%$ \\
Leaning Republican & $17.39 \%$ \\
Mostly Republican & $23.27 \%$ \\
Completely Independent & $21.99 \%$ \\
Not sure & $9.97 \%$ \\
Did not answer & $3.32 \%$ \\
\hline
\end{tabular}




\section{Responses to WTP Valuation Questions}

Additional evidence of support for the National Parks and NPS programs is found in the large percentage of respondents willing to pay some amount to prevent cuts. Table 7 below shows the least preferred option selected by respondents, grouped according to the most preferred option selected. Column headings show the most preferred option and row labels show the breakdown of least preferred option for each group. (Note that for each of the options a few respondents indicated the same option as both their most preferred and least preferred, indicated by italicized text). The row indicating "did not answer" refers to those respondents who answered the "most preferred" question but did not answer the "least preferred" question. The column total is percentage of the sample who selected that option as "most preferred." This row sums to the total percentage of respondents who answered the "most preferred" question (which is less than $100 \%$ of the sample).

Table 7. Responses to Most Preferred and Least Preferred Option

\begin{tabular}{|c|c|c|c|c|}
\hline \multirow{2}{*}{\multicolumn{2}{|c|}{ Parks }} & \multicolumn{3}{|c|}{ Most Preferred Parks Option } \\
\hline & & $\begin{array}{l}\text { Option A - Sale of some } \\
\text { land in all parks }\end{array}$ & $\begin{array}{l}\text { Option B - Smaller lands sales } \\
\text { in some or all parks at low cost }\end{array}$ & $\begin{array}{l}\text { Option } \mathrm{C} \text { - No sale of } \\
\text { parks at higher cost }\end{array}$ \\
\hline \multirow{5}{*}{ 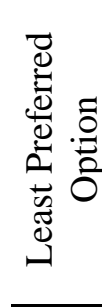 } & Option A & $1.69 \%$ & $18.36 \%$ & $41.95 \%$ \\
\hline & Option B & $0.14 \%$ & $1.69 \%$ & $3.25 \%$ \\
\hline & Option C & $9.75 \%$ & $10.88 \%$ & $3.67 \%$ \\
\hline & Did not answer & $1.13 \%$ & $0.71 \%$ & $0.56 \%$ \\
\hline & Total & $12.71 \%$ & $31.64 \%$ & $49.44 \%$ \\
\hline \multirow{2}{*}{\multicolumn{2}{|c|}{ Programs }} & \multicolumn{3}{|c|}{ Most Preferred Program Option } \\
\hline & & $\begin{array}{l}\text { Option D - Cuts to all } \\
\text { programs }\end{array}$ & $\begin{array}{c}\text { Option } \mathrm{E} \text { - smaller cuts to some } \\
\text { or all programs }\end{array}$ & $\begin{array}{l}\text { Option } \mathrm{F} \text { - no cuts to } \\
\text { programs at higher cost }\end{array}$ \\
\hline \multirow{5}{*}{ 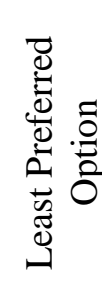 } & Option D & $1.84 \%$ & $24.14 \%$ & $26.93 \%$ \\
\hline & Option E & $1.13 \%$ & $1.98 \%$ & $1.72 \%$ \\
\hline & Option F & $12.71 \%$ & $16.81 \%$ & $1.72 \%$ \\
\hline & Did not answer & $0.71 \%$ & $1.55 \%$ & $1.41 \%$ \\
\hline & Total & $16.38 \%$ & $45.48 \%$ & $31.36 \%$ \\
\hline
\end{tabular}

Table 8 shows responses to the consequentiality questions that elicit respondent's views of the significance or importance of their answers in shaping policy regarding NPS parks and programs. About half of the respondents were uncertain that their answers would be used to inform policy decisions (48.9\% responded that they were either "uncertain" or "very uncertain" that the results would be used to formulate policy). However many respondents are certain they would have to pay the tax (47\% responded that they are either "certain" or "very certain" that they would have to pay the tax described). This last response suggests that many respondents treated their answers as potentially having real tax consequences to their household. 
Table 8. Respondent beliefs about consequentiality of the survey

\begin{tabular}{lcc}
\hline & $\begin{array}{c}\text { Answers will be used } \\
\text { for decisions }\end{array}$ & $\begin{array}{c}\text { Will actually have } \\
\text { to pay tax }\end{array}$ \\
\hline Very certain & $5.79 \%$ & $17.23 \%$ \\
\hline Certain & $9.18 \%$ & $31.36 \%$ \\
\hline Neither certain nor uncertain & $34.04 \%$ & $29.38 \%$ \\
\hline Uncertain & $29.24 \%$ & $13.42 \%$ \\
\hline Very uncertain & $17.66 \%$ & $4.24 \%$ \\
\hline Did not answer & $4.10 \%$ & $4.38 \%$ \\
\hline
\end{tabular}

Since we chose annual increase in federal income taxes as a realistic means of payment to prevent the sale of National Parks or to avoid cuts to NPS programs there is a possibility that some respondents indicated a WTP of zero as a "protest" of the payment vehicle. A protest response occurred when some premise of the National Parks or NPS Program scenario was rejected by the respondent (for example, they were opposed to the concept of taxes as a way to pay for retaining parks). Thus their response reflects a protest against how they are being asked to pay rather than the true value that they ascribe to the public good. Protest zeros could reflect attitudes toward the federal government, objections to paying taxes, or even objections to the survey in general.

To attempt to separate protest responses from valid zero WTP responses, we asked respondents selecting the maximum sale/maximum cut a follow-up question about the reason for their zero WTP. Thirteen percent of respondents who indicated a willingness to pay of zero for the National Parks choice question and $17 \%$ of zero WTP respondents to the Programs choice question indicated that either they could not afford the amount or that the National Parks or NPS Programs were not worth the amount asked. This indicates that respondents were, in fact cognizant of their budget constraints and of their personal valuations for the National Parks or NPS Programs. Such reasons for a zero WTP are not a protest since zero reflects the true willingness and ability to pay.

Only about $7.5 \%$ of respondents to the National Parks choice question (58.9\% of those choosing Option $\mathrm{A} 2$ and $9.2 \%$ of respondents to the programs choice question ( $56 \%$ of those choosing Option D) were determined to be general "protest" responses (see the appendix for more details on the protest responses) ${ }^{23}$ This relatively low rate of protest response suggests that our "simulated market" and scenario was accepted by more than $90 \%$ of respondents. It should be noted that we included all responses to the questionnaire, even though it is acceptable to delete protests as not reflecting the respondent's true value (Mitchell and Carson 1989). Retaining the protest households who declined to pay provides a conservative estimate of overall willingness to pay.

\footnotetext{
${ }^{23}$ Some respondents who selected Options B or C for Parks, or E or F for Programs (indicating a willingness to pay greater than $\$ 0)$ answered the protest detection question and some of these responses could also be construed as protests. These are noted in Table 8. If these are included the total, protest responses increase for Parks to $12.4 \%$ and to $14.8 \%$ for Programs.
} 


\section{Statistical Analyses and Results}

The survey asked respondents to select the most preferred and least preferred among three different options for both Parks and Programs. This approach enables us to infer a ranking for the three options. The most preferred option alone provides only an indication of the respondents' top choice and does not contain as much information about the respondent's values as a ranking of all three options. Using the additional information in a rank-ordered logit (logistic regression) provides more efficient estimators for the coefficients. This in turn allows us more confidently to derive incremental (marginal) values for the various attributes of the National Parks and NPS programs.

The attributes for the National Parks are the remaining acres (or sites) of each of the three types of park after any sales are made. Option A includes sale of some land in all types of parks (in varying amounts). Option B includes smaller sales of land in some or all types. Option C has no land sales. The three options for programs are similar: one with cuts to all types, one with smaller cuts and one with no cuts. The attributes for programs are the amounts of the annual flow of outputs remaining for the four types of programs after any program cuts are made.

By using most preferred and least preferred options, the data can be configured into what is essentially a panel with each respondent having three lines of data (one for each of the three survey options). Each of these lines of data includes the attribute levels of that option (including price) and the implied rank of that option derived from the most preferred and least preferred (incomplete responses were dropped from the analysis). We then used the implicit ranking of each option as the dependent variable in a rank-ordered logit model with the attribute levels for each option as the right-hand-side explanatory variables.

As described above, our raw sample is not completely representative of some demographic characteristics nor of the National Park visitation rate of the population as a whole. However, as a first step we estimated the rank-ordered logistic model without any adjustments for such differences. Although this model performed well, we felt that the incremental (marginal) and total economic values might not reflect the population's true willingness to pay.

To adjust for differences between respondents' National Park visitation rates and sample demographics, we used a statistical routine to reweight the sample observations to reflect population characteristics. ${ }^{24}$ Weighting by visitation yielded the most conservative valuations. Furthermore, since demographics are often determinants of National Park visitation (Henrickson and Johnson 2013, Neher et al. 2013), weighting on visitation may implicitly adjust for demographics as well.

We also employed a sample weighting procedure to adjust for differences in income and other demographics (based on the U.S. Census) and visitation rate. The statistical software used for these analyses (Stata) includes an algorithm ("ipfweight") for adjusting sample proportions to conform more closely to population proportions (called "raking"). The algorithm generates a weight variable for each observation through an iterative process based on the values for the population as a whole. For our analysis we created three different weights. One adjusted for differences in education level, age, income, race and work status (retired or not). A second adjusted for all of these demographic characteristics plus the proportion of the population that visited a National Park. The final weighting accounted only for

\footnotetext{
${ }^{24}$ Specifically, the statistical software (Stata) constructed a weight for each respondent based on their specific demographic characteristics relative to the U.S. population by comparing the survey sample proportions with the proportions based on the most recent U.S. Census. For example, less educated, younger minorities are underrepresented in the sample, so these respondents' answers were given a larger weight than more educated, white retirees with higher incomes (who were over-represented in the sample). National Park visitors are also overrepresented and thus were weighted less than non-visitors. We constructed three sets of weights - one based on demographic characteristics only, one based just on visitation and a third based on both demographics and visitation.
} 
National Park visitation (which, as already noted, may implicitly account for demographics, since demographics are determinants of visitation).

We estimated several rank-ordered logit models in which weights were used to account for demographic differences and visitation rates..$^{25}$ Our total economic value results are quite robust to the various weighting procedures (see Appendix B: Additional Models). The results reported here in the main report are those from the best performing model (providing the most statistically efficient coefficient estimates - smallest standard errors - and therefore yielding the tightest confidence intervals around WTP) and the one that also yielded the lowest estimates of total economic value.

The National Parks model summarized in Table 9 performs well overall. Each individual coefficient is significant at the $99 \%$ confidence level and all have the expected sign. Most importantly, the coefficient on the annual cost of each option (tax) is negative and statistically significant, indicating respondents were paying close attention to the cost of each option. Put another way, the negative sign indicates that the higher the cost of that option, the less likely respondents were to choose it. Thus respondents appear to be making rational economic choices. Furthermore, the Wald statistic (distributed Chi-Square) indicates that the overall model is statistically significant.

Table 9. Results for National Parks - Rank-ordered Logit - weighted for NP visitation

\begin{tabular}{lcccc}
\hline Dependent variable = Rank of the NPS Park policy option & & & \\
& Coefficient & Std. Error & $\mathbf{Z}$ & $\mathbf{P}>|\mathbf{z}|$ \\
\cline { 2 - 5 } Annual cost of option (federal income tax) & -0.0017724 & 0.0002924 & $-6.06 * * *$ & 0.000 \\
Nature-focused NPS (cuts avoided) & $2.49 \mathrm{E}-08$ & $6.99 \mathrm{E}-09$ & $3.57 * * *$ & 0.000 \\
History-focused NPS (cuts avoided) & 0.0068598 & 0.0017039 & $4.03 * * *$ & 0.000 \\
Water-focused NPS (cuts avoided) & $3.60 \mathrm{E}-07$ & $1.14 \mathrm{E}-07$ & $3.14 * * *$ & 0.002 \\
\hline
\end{tabular}

Number of observations $=1941$

Number of groups $=647$

Wald Chi-Sq( 4) = 232.03

Log pseudo-likelihood = (3 observations per groups)

Prob $>$ Chi-Sq $=0.0000$ 1133.892

*** significant at $99 \%$ confidence level

Results for NPS programs are shown in Table 10. As with the parks model, the programs model performs well overall. All of the coefficients have the expected signs, and all but one (transfer of recreation lands to communities) are significant at the $95 \%$ level or higher. The Wald statistic indicates the overall model is statistically significant as well.

\footnotetext{
${ }^{25}$ Results for additional models estimated can be found in the Appendix.
} 
Table 10. Results for National Park Programs - Rank-ordered Logit - weighted for NP visitation Dependent variable $=$ Rank of the NPS Program policy option

Annual cost of option (federal income tax)

\begin{tabular}{cccc} 
Coefficient & Std. Error & $\mathbf{Z}$ & $\mathbf{P}>|\mathbf{z}|$ \\
\hline-0.0041514 & 0.0003244 & $-12.8 * * *$ & 0.000 \\
0.0006566 & 0.0002887 & $2.27 * *$ & 0.023 \\
0.0001513 & 0.0002011 & 0.75 & 0.452 \\
0.012672 & 0.0051371 & $2.47 * *$ & 0.014 \\
$6.91 \mathrm{E}-07$ & $1.09 \mathrm{E}-07$ & $6.33^{* * *}$ & 0.000
\end{tabular}

Historic sites and buildings protected each year (cuts avoided)

Acres transferred to communities each year (cuts avoided)

Natural landmarks protected each year (cuts avoided)

School children served by NPS educational programs each year (cuts avoided)

Number of observations $=1902$

Number of groups $=634$ (3 observations per groups)

Log pseudo-likelihood $=$ 1117.304

*** significant at $99 \%$ confidence level, ** significant at $95 \%$ confidence level, * significant at $90 \%$ confidence level 


\section{Estimates of Economic Value for National Parks and NPS Programs}

The marginal or implicit prices for each type of National Park and NPS Program are estimated individually per unit (per acre, per site or per student). These marginal values are then multiplied by the number of acres, sites or students to arrive at a total value for each attribute. We then calculate Total Economic Value (TEV) by summing these park- or program-specific values.

Incremental (marginal) values for the attributes are calculated as the ratio of the attribute coefficient over the price coefficient (Holmes and Adamowicz 2003). Stata has a command that calculates the ratio and estimates the standard error and a confidence interval for this ratio (i.e., the incremental value). This gives us a range within which the estimated marginal and total values fall. The values implied by the rankordered logit regression results are shown in Table 11 (National Parks) and Table 12 (NPS Programs).

The last row in Table 11 labeled "All National Parks" contains two estimated values. The first is the TEV calculated based on the range of acres and historic sites protected (cuts avoided) presented in the survey. The avoided cuts that households were "buying" range from $10 \%$ to $40 \%$ of all National Parks. Thus the row labeled "TEV survey cuts avoided" reflects the sample range of cuts. The resulting WTP amounts are quite reasonable, with TEV amounting to $\$ 523.86$ per household, with a $95 \%$ confidence interval of $\$ 377.52$ to $\$ 670.19$. Unfortunately there are few other nationwide land preservation programs with which to compare our estimates. Just to provide some perspective, Walsh, et al. (1984) found Colorado households would pay on average $\$ 91.14$ (in 2014 dollars) to protect just 10 million acres of roadless land as Wilderness. Carson and Mitchell (1993) estimated the benefits of improving national water quality to swimmable conditions at \$438 per household (in 2014 dollars). Our per-household values for the cuts avoided are consistent with other nationwide environmental quality programs.

Table 11. Marginal and Per-Household Total Economic Values (TEV) for National Park Lands, Waters and Historic Sites

\begin{tabular}{|c|c|c|c|c|}
\hline & & $\begin{array}{l}\text { Estimated } \\
\text { value }\end{array}$ & $\begin{array}{r}95 \% \text { Confider } \\
\text { Estimat }\end{array}$ & $\begin{array}{l}\text { e Interval for } \\
\text { d Value }\end{array}$ \\
\hline \multirow{3}{*}{$\begin{array}{l}\text { Nature-focused } \\
\text { National Parks } \\
(79,096,632 \text { acres })\end{array}$} & Marginal Value (per acre) & $\$ 0.0000141$ & $\$ 0.000006$ & $\$ 0.00002 .21$ \\
\hline & Per household TEV for survey cuts avoided & $\$ 189.21$ & $\$ 83.54$ & $\$ 294.88$ \\
\hline & Per household Total Economic Value for all acres & $\$ 1,113.24$ & $\$ 491.51$ & $1,734.97$ \\
\hline \multirow{3}{*}{$\begin{array}{l}\text { History-focused } \\
\text { National Parks } \\
\text { (226 sites) }\end{array}$} & Marginal Value (per site) & $\$ 3.87$ & $\$ 1.74$ & $\$ 6.00$ \\
\hline & Per household TEV for survey cuts avoided & $\$ 148.66$ & $\$ 66.75$ & $\$ 230.57$ \\
\hline & Per household Total Economic Value for all sites & $\$ 874.71$ & $\$ 392.75$ & $\$ 1,356.68$ \\
\hline \multirow{3}{*}{$\begin{array}{l}\text { Water-focused } \\
\text { National Parks } \\
(4,818,275 \text { acres })\end{array}$} & Marginal Value (per acre) & $\$ 0.000203$ & $\$ 0.00005 .99$ & $\$ 0.000346$ \\
\hline & Per household TEV for survey cuts avoided & $\$ 185.99$ & $\$ 54.90$ & $\$ 317.08$ \\
\hline & Per household Total Economic Value for all acres & $\$ 977.93$ & $\$ 2,88.64$ & $\$ 1,667.22$ \\
\hline \multirow[b]{2}{*}{ All National Parks } & Per household TEV for survey cuts avoided & $\$ 523.86$ & $\$ 377.52$ & $\$ 670.19$ \\
\hline & $\begin{array}{l}\text { Per household Total Economic Value for all } \\
\text { acres/sites }\end{array}$ & $\$ 2,967$ & $\$ 2,144$ & $\$ 3,787$ \\
\hline
\end{tabular}


Table 12. Marginal and Per-Household Values for NPS Programs

\begin{tabular}{|c|c|c|c|c|}
\hline & & $\begin{array}{l}\text { Estimated } \\
\text { Value }\end{array}$ & $\begin{array}{l}95 \% \text { Confide } \\
\text { for Estima }\end{array}$ & $\begin{array}{l}\text { ce Interval } \\
\text { ed Value }\end{array}$ \\
\hline \multirow{3}{*}{$\begin{array}{l}\text { Historic sites and } \\
\text { buildings protected } \\
\text { each year }(2,000)\end{array}$} & Marginal Value (per site) & $\$ 0.16$ & $\$ 0.02$ & $\$ 0.29$ \\
\hline & Per household TEV for survey cuts avoided & $\$ 48.40$ & $\$ 7.47$ & $\$ 89.32$ \\
\hline & Per household Total Economic Value for all sites & $\$ 316.31$ & $\$ 48.82$ & $\$ 583.80$ \\
\hline \multirow{3}{*}{$\begin{array}{l}\text { Acres transferred to } \\
\text { communities each } \\
\text { year }(2,700)\end{array}$} & Marginal Value (per acre) & $\$ 0.04$ & $\$ 0$ & $\$ 0.13$ \\
\hline & Per household TEV for survey cuts avoided & $\$ 15.20$ & $\$ 0$ & $\$ 54.60$ \\
\hline & Per household Total Economic Value for all acres & $\$ 98.41$ & $\$ 0$ & $\$ 353.53$ \\
\hline \multirow{3}{*}{$\begin{array}{l}\text { Natural landmarks } \\
\text { protected each year } \\
(114)\end{array}$} & Marginal Value (per site) & $\$ 3.05$ & $\$ 0.71$ & $\$ 5.40$ \\
\hline & Per household TEV for survey cuts avoided & $\$ 54.94$ & $\$ 12.75$ & $\$ 97.14$ \\
\hline & Per household Total Economic Value for all sites & $\$ 347.98$ & $\$ 80.74$ & $\$ 615.22$ \\
\hline \multirow{3}{*}{$\begin{array}{l}\text { School children } \\
\text { served by NPS } \\
\text { educational programs } \\
\text { each year ( } 4.1 \\
\text { million) }\end{array}$} & Marginal Value (per student) & $\$ 0.000167$ & $\$ 0.000109$ & $\$ 0.000224$ \\
\hline & Per household TEV for survey cuts avoided & $\$ 135.29$ & $\$ 88.73$ & $\$ 181.84$ \\
\hline & $\begin{array}{l}\text { Per household Total Economic Value for all } \\
\text { students }\end{array}$ & $\$ 682.62$ & $\$ 447.70$ & $\$ 917.53$ \\
\hline \multirow{2}{*}{$\begin{array}{l}\text { All Programs } \\
\text { Outcomes }\end{array}$} & Per household total value for cuts avoided & $\$ 253.82$ & $\$ 226.68$ & $\$ 280.97$ \\
\hline & $\begin{array}{l}\text { Per household Total Economic Value for all } \\
\text { NPS Programs }\end{array}$ & $\$ 1,445$ & $\$ 1,290$ & $\$ 1,601$ \\
\hline
\end{tabular}

The final rows of Tables 11 and 12 represent scaling up the per acre or per site values to the entire National Park System (Table 11) and NPS Programs (Table 12) to arrive at a comprehensive total for the all National Parks and NPS programs.

This scaling up assumes the values per acre are linear. This is a typical convention used in applying the marginal values or implicit prices from a choice experiment. We tested for non-linearity using a quadratic rank-ordered logit model. None of the squared terms was statistically significant, and the overall performance of both non-linear rank-ordered logit models was inferior to the models presented in Tables 9 and 10. The lack of significance of the quadratic terms suggests that marginal values may in fact be linear over the range of our data.

However, when scaling up to all National Parks and NPS Programs we go beyond the range of the cuts in the survey. Given that we are extrapolating from the relatively flat portion of the Total Economic Value function backwards to the origin we have probably understated the Total Economic Value (see Figure 1).

Figure 1 (below) is a stylized version of a typical Total Benefits curve. This curve reflects the economic principle of diminishing marginal benefits. The principle states that as the quantity consumed of an identical good increases, the incremental gain in total benefits from each additional unit is a bit smaller than the benefit derived from prior units. This is easily seen when considering market goods, but it also applies to increasing quantity of an identical public good (Rollins and Lyke 1998). If there were no National Parks or NPS programs, the addition of the first National Park would have great value. 
Figure 1. Diminishing Marginal Benefit of the National Parks and Programs

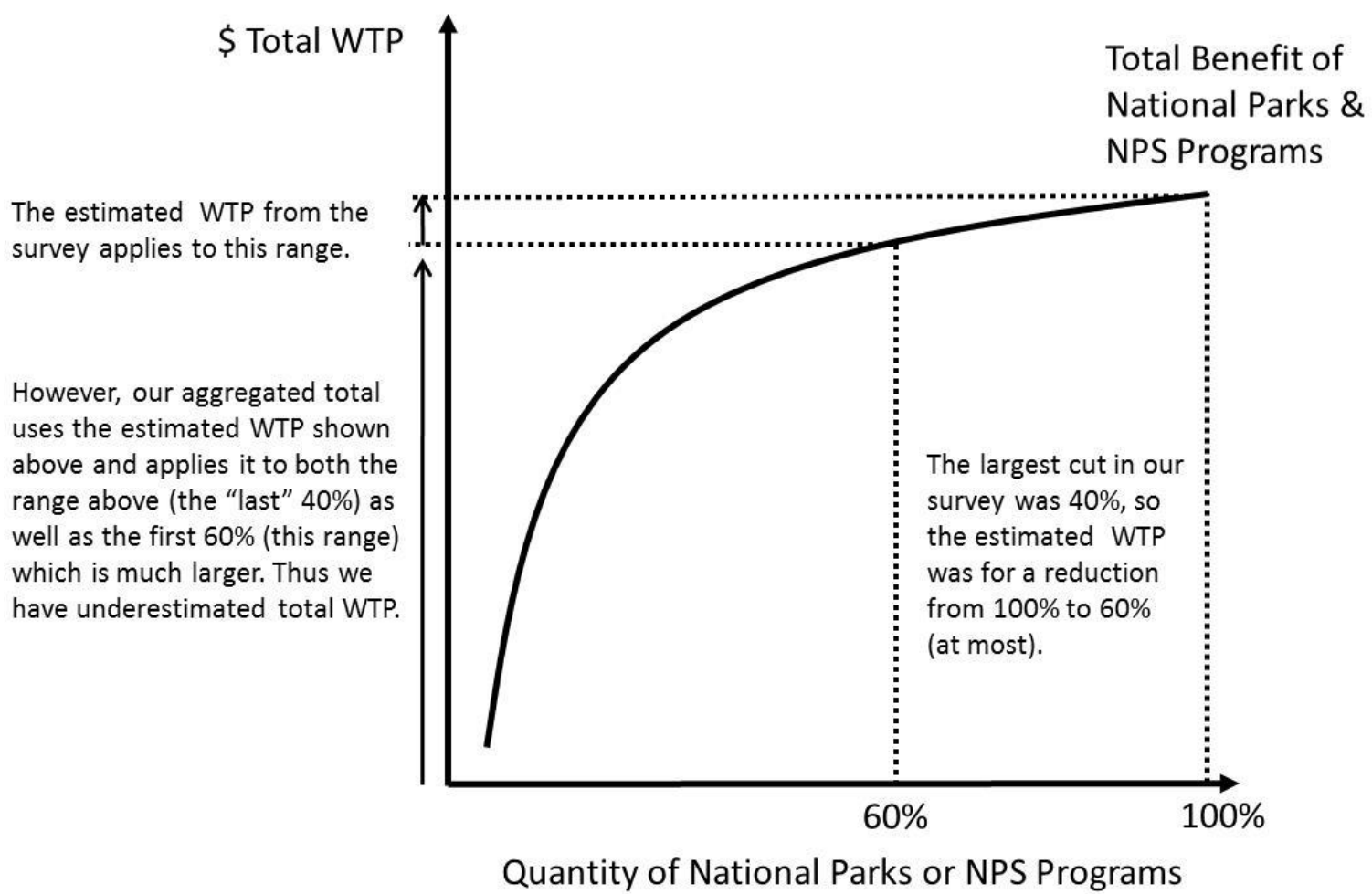

While it would have been ideal to ask households what they would have paid to avoid selling all the National Park units and stopping all NPS Programs, we felt this was not a credible scenario. In order to provide a realistic policy scenario in the survey, we proposed taking away only a portion of the National Parks and NPS programs due to budget cuts and the federal deficit. As illustrated in Figure 1, we took our per household values for $20 \%$ to $40 \%$ reductions in National Parks, and then applied that value for the average $20 \%$ cut to all $100 \%$ of the Parks or programs. The Parks and programs being "bought back" by survey respondents are in the flatter portion of the Total Economic Value curve due to diminishing marginal benefit (Rollins and Lyke 1998 and Walsh et al. 1984). Thus, the WTP to avoid the cuts proposed in the survey (20\% to 40\%) would likely be lower than the WTP to avoid cuts to the remaining $60 \%$ of National Parks and NPS programs. By applying the estimated marginal value to all the units and all the program outputs we are likely underestimating the total value of the National Park System in its entirety.

Despite this downward bias in our approach, scaling our estimate of WTP to avoid an average of $20 \%$ cuts and applying it to the WTP for maintaining 100\% of the entire National Park System results in a substantial figure of $\$ 2,967$ a household. The equivalent WTP for all (100\%) of the NPS Programs is $\$ 1,445$ per household. While the sum of these two WTPs is quite large, a typical household in our sample could still theoretically afford to pay it since the sum of the two figures represents about $7 \%$ of our samples' average household income. For lower income households, some might be able to afford to pay to avoid the $20 \%$ cuts but not to pay to avoid the full $100 \%$ cuts, since this amount would exceed their budget constraint. However, it must be remembered that an average WTP means that half the sample would pay this amount or more, while the other half would pay this amount or less. The "average" WTP per household does not imply that each and every household would pay the average amount. For example, 
households that report they have visited National Parks in the last two years have higher Total Economic Values (TEV) since their TEVs include both visitor use and non-use/passive-use value. Households that do not visit National Parks have lower values per household since their TEVs are purely non-use/passiveuse and do not include any current visitor use value. This can be seen by comparing WTP of visitors and non-visitors in Appendix Table B3.

It is worth noting that the values we estimated for the National Parks are much higher than those for the NPS programs. This is an indication that when confronted with an irreversible change (the sale of National Parks) the amount respondents would pay to avoid such an irreversible loss is higher than the amount they would pay to avoid what they may perceive as potentially reversible program cuts. Specifically this difference in economic values is likely due to the nature of these two public goods. The questionnaire proposed selling lands and sites within the National Park Service system. This would be an irreversible change. Reducing the funding for many of the NPS programs, on the other hand, is potentially reversible at some future date. It may result in some lost opportunities for historic or natural preservation but (as noted above) many of the iconic examples are protected within the Park system.

\section{Calculating National Total Economic Value of National Parks and NPS Programs}

We utilized income taxes as the way households would pay to prevent a reduction in the number of National Park lands/waters and historic sites, not because we propose that households should pay higher taxes but because taxes are a recommended, realistic and conservative way to elicit the amount that a household would pay for a public good (Carson and Groves 2007).

Despite starting with a representative sample, and using multiple mailings and reminders to complete the survey, our responding households had slightly higher incomes, higher education, and were older than the typical U.S. household. In addition we had a slightly higher proportion of National Park visitors in our sample compared to an independent survey of American households. Therefore in our non-market valuation analysis we used a standard statistical procedure to reweight the sample observations to reflect the population. We explored different variables to weight on, and choose the model that gave us the most conservative value, adjusting just for the National Park visitor percentages (the valuation estimates based on weighting for demographics and visitors were quite similar, just slightly higher).

Furthermore, in order to be extremely conservative in our valuation, we assumed that those households not responding to the survey after repeat mailings would not pay anything for preservation of National Parks or NPS programs. Using our response rate of $18 \%$ we took the average per household value estimated from our sample and multiplied it by $18 \%$ of the U.S. households (18\% of 115.6 million U.S. households) and assumed zero benefits for the remaining $82 \%$ of households. This clearly understates the total value, since many households may simply choose not to answer lengthy surveys such as ours (12 pages) while still placing some value on National Parks and NPS programs.

Using this procedure our conservative estimated value is $\$ 92$ billion, of which $\$ 62$ billion is for National Parks and $\$ 30$ billion for NPS Programs which often exist outside the geographical boundaries of NPS units. Such programming is often cooperative in nature, with the NPS providing the backbone that holds together thousands of small jurisdictions and stakeholders in support of historical preservation, environmental stewardship, education and recreational opportunities in the communities.

We conclude that the estimated value of $\$ 62$ billion for National Parks is highly credible given that Neher, et al. (2013) estimated the recreation use value alone for the National Parks at $\$ 28.5$ billion. It makes sense that total economic value - which includes recreation use values and passive or non-use values - would be significantly larger. If we subtract the Neher, et al. estimate from our total economic value for National Parks, it yields an estimate of $\$ 33.5$ billion for the purely passive or non-use valuethat is the existence and bequest value derived by the American public from just knowing that National Parks exist and will be available for future generations. 
We believe our findings are quite conservative. A model based on weighting by Park visitation and demographics yielded $\$ 67$ billion for National Parks and \$32 billion for NPS Programs, for a total of $\$ 99.5$ billion.

Not only are the value calculations conservative, but they are based on what a household would pay to avoid sale of National Parks that they already collectively own. As discussed earlier in this report, in policy scenarios involving reducing the quantity or quality of a natural resource the public already "owns" or has a right to, willingness to accept (WTA), not willingness to pay, should be used as a measure of economic value. If we had chosen to conduct a choice experiment using WTA, the national values would likely have been much higher.

Our values are also in line with WTP estimates from other nationwide CVM surveys regarding environmental programs. Carson and Mitchell (1993: 2452) estimated a value of improving America's rivers and lakes to a swimmable water quality at $\$ 29.2$ billion in 1983, equivalent to $\$ 69.5$ billion in 2015 dollars. This estimate is similar in magnitude to our estimate of the value of National Parks lands, waters and historic sites. A CVM study of the national benefits of maintaining air quality over just three southwest U.S. National Parks (Grand Canyon, Mesa Verde and Zion) was estimated by Schulze, et al. (1983: 166) at $\$ 6.1$ billion in 1980, with inflation adjusted benefits of $\$ 17.8$ billion in 2015. Given, that the Schulze et al. value is just for maintaining air quality over these three National Parks, not transferring them to the private sector, it suggests our estimates for maintaining the entire National Park System lands, waters and historic sites are conservative.

In short, the $\$ 92$ valuation represents the minimum amount that US households are willing to pay to avoid the loss of the NPS and its programs. We have adopted a conservative approach in several ways summarized below:

- Attributing value to the $18 \%$ of households who responded to the survey, attributing zero value to the remaining $82 \%$. (As noted earlier, our follow-up sample confirmed that most non-respondents failed to respond due to factors that were un-related to the national parks, and indeed are overwhelmingly favorable to national parks.)

- Using "willingness-to-pay" (WTP) to keep National park lands/waters/historic sites instead of the more appropriate "Willingness-to-accept" (WTA) to give up these places that people already own. WTA is usually much larger than WTP for public goods.

- The survey did not drop "protest responses"-people who indicate they would not pay not because they don't value National Parks or can't afford to pay but for other reasons such as rejecting one or more premises of the survey-what is sometimes call scenario rejection.

- Valuing only a $20 \%$ to $40 \%$ reduction in National Park lands/waters and historic sites, but assumed that same value per acre or per site applied all the way to loss of $100 \%$ of all National Park lands/waters and historic sites. This is akin to estimating that a person would value the loss of five fingers at five times the value of losing one finger-when in fact a person would pay more to avoid the loss of all five fingers.

- Selecting the economic valuation model that gave us the lowest estimate of what households would pay.

- Excluding questions on the value of additional NPS activities, such as scientific research, ecosystem services and other sources of value.

The study could be improved upon in the future with a larger survey sample that would more accurately reflect the composition of the US population as a whole. In addition, a larger post-survey non-response follow up effort might have allowed for a more precise weighting adjustment procedure to deal with any potential sample selection bias. Such limitations could have been addressed with a larger budget. 


\section{Conclusion}

Our results indicate that the American public's value for the non-market public goods produced by the National Park Service is substantial. The lands, waters, historic sites and programs of the National Park System are worth $\$ 92$ billion-at a minimum.

Of the $\$ 62$ billion that is related just to the geographical holdings of NPS, less than half of this represents the value of recreational use. The remainder is the value that American households place on just knowing that lands, waters and historic sites of the National Park System exist and will be available for future generations.

The NPS's educational programs and programs aimed at conservation, education, and stewardship of historic and cultural sites are valued by the American public at $\$ 30$ billion. These programs benefit millions of Americans who visit protected properties as well as large numbers of teachers and students who use educational curricula materials developed by NPS. This figure may well underestimate the value that the public places on the NPS role in protecting ecosystems, watersheds, intellectual property and other assets that were not specifically tested in this survey.

Despite these limitations, we are confident that our estimates represent a minimum economic value for NPS assets and programs. The results are based on a highly conservative methodology. Our value calculations omit completely the economic value of the NPS to hundreds of millions of people worldwide, a significant number of whom come as tourists to visit the National Parks, or who value the existence of these places. Moreover the findings are supported by a number of recent opinion that polls that provide evidence of strong support for public lands in general ${ }^{26}$ and the National Parks in particular. ${ }^{27}$

Our findings should be of interest both to researchers and to policymakers when considering the appropriate level of budgetary resources needed to maintaining this significant national asset.

\footnotetext{
${ }^{26}$ National Forest Foundation 2013 poll http://www.nationalforests.org/poll, Colorado College Conservation in the West Poll 2013 http://www.coloradocollege.edu/stateoftherockies/conservationinthewest/

${ }^{27}$ National Parks Conservation Association poll 2012 http://www.npca.org/protecting-our-parks/policy-legislation/nationalparks-poll.html
} 


\section{Acknowledgements}

This report benefited from survey design and review of statistical analysis provided by Dr. Barbara Kanninen of BK Econometrics, and initial study design and draft report review by Dr. John Duffield, University of Montana. We are grateful for the assistance of Dr. Brian Harnisch at Wyoming Survey and Analysis Center, University of Wyoming, Laramie, WY. Additional review and input was gratefully received from Dr. Dan McCollum and Dr. Tom Holmes of the U.S.D.A. Forest Service and Brian Quay, now with the U.S. Geological Survey.

We also acknowledge the contributions of several individuals at the Harvard Kennedy School, including former students Adam Banasiak, Francis Choi, Timothy Marlowe, Stephen Thompson and Thomas Liu; and Scott Leland of the Mossavar-Rahmani Center for Business and Government.

We benefitted from the input and assistance of a number of individuals in the National Park Service, including Dr. Bruce Peacock, Director Jonathan Jarvis, Loran Fraser, Dr. Lynne Koontz, Dr. Leslie Richardson, and numerous NPS employees at units including Minute Man Historical Park, Golden Gate NRA, Ellis Island, Joshua Tree, Everglades, Saguaro, Chesapeake Bay and Santa Monica NRA. We also thank a number of people who have advised us on portions of the research, including Dr. Milton Chen, Dr. Rita Colwell, Dr. Sylvia Earle, Professor Henry Louis Gates, Jr., Belinda Faustinos, Gretchen Long, Dr. Colin Mayer (Oxford University). We also thank the members of the NPS Advisory Committee and the members of the NPCA Second Century Commission who first envisaged this project.

We are grateful for the funding for this research, which has been provided by the S. D. Bechtel, Jr. Foundation, the Turner Foundation, Cody J. Smith (Summit Foundation), the National Park Foundation and UPD Consulting. We especially thank Tina Batt and Cody J. Smith for their vision in bringing this study to fruition.

None of these funding groups or individuals is responsible for the content of the report and conclusions, which are solely those of the authors. 


\section{References}

Arrow, K., R. Solow, P. Portney, E. Leamer, R. Radner and H. Schuman. 1993. Report of the NOAA Panel on Continent Valuation. http://www.economia.unimib.it/DATA/moduli/7_6067/materiale/noaa\%20report.pdf (Also published in Federal Register Jan. 15, 1993, 4601-4614.)

Banasiak, Adam, Bilmes, Linda J. and Loomis John. 2015. Carbon Sequestration in the U.S. National Parks: A Value Beyond Visitation, HKS Working Paper No. RWP15-007.

Bennett, J. and R. Blamey. 2001. The Choice Modelling Approach to Environmental Valuation. Edward Elgar Publishing Ltd: Cheltenham UK. 269 p.

Berrens, R. P. , A. K. Bohara, H. C. Jenkins-Smith, C. L. Silva and D. L. Weimer. 2004. Information and effort in contingent valuation surveys: application to global climate change using national internet samples. Journal of Environmental Economics and Management 47: 331-363.

Boyle, K. J. and M. A. Markowski. 2003. Estimating Non-Use Values for National Park System Resources. White paper obtained from authors.

Carlsson, R., P. Frykblom, and C. J. Lagerkvist. 2005. Using cheap talk as a test of validity in choice experiments. Economics Letters 89(2):147-152

Carson, R. T. and T. Groves. 2007. Incentive and informational properties of preference questions. Environmental and Resource Economics 37:181-201.

Carson, R. and R.C. Mitchell. 1993. The Value of Clean Water: The Public's Willingness to Pay for Boatable, Fishable and Swimmable Quality Water. Water Resources Research 29(7): 2445-2454.

Champ, P. A., K. J. Boyle, and T. C. Brown. 2003. A Primer on Nonmarket Valuation. Kluwer Academic Publishers: Norwell MA. 576 p.

Choi, F. and T. Marlow. 2012. The Value of America's Greatest Idea: Framework for Total Economic Valuation of National Park Service Operations and Assets and Joshua Tree National Park Total Economic Value Case Study. A report provided to the National Park Service, developed for the Policy Analysis Exercise Requirement at the Harvard Kennedy School of Government. 87 pp.

Cummings, R. G. and L. O. Taylor. 1999. Unbiased value estimates for environmental goods: A cheap talk design for the contingent valuation method. The American Economic Review, 89(3): 649-665.

Douglas, A. J. and D. A. Harpman. 2004. Lake Powell management alternatives and values: CVM estimates of recreation benefits. Water International 29(3): 375-383.

Duffield, J. W. 2006. Economic Values of National Park System Resources Within the Colorado River Watershed. Report prepared for the National Park Service Environmental Quality Division, Cooperative Agreement H1200040002, Task J2380050112. 47 p.

Evans, J. R. and A. Mathur. 2005. The value of online surveys. Internet Research 15(2): 195-210.

Freeman, A. M. 2003. The Measurement of Environmental and Resource Values: Theory and Methods. Second edition. Resources for the Future, Washington D.C. 491pp.

Grandjean, B. D., N. M. Nelson, and P. A. Taylor. 2009. Comparing an internet panel survey to mail and phone surveys on willingness to pay for environmental quality: a national mode test. Paper Presented at the 64th Annual conference of the American Association for Public Opinion Research, 14-17 May 2009. 5779-5793. 
Hanemann, M. 1991. Willingness to Pay and Willingness to Accept: How Much Can They Differ? American Economic Review 81(3): 635-647.

Heberling, M. T. and J. J. Templeton. 2009. Estimating the economic value of national parks with count data models using on-site, secondary data: the cast of the Great Sand Dunes National Park and Preserve. Environmental Management 43: 619-627

Henrickson, K. and E. Johnson. 2013. The Demand for Spatially Complementary National Parks. Land Economics 89(2): 330-345.

Hensher, D. A., J. M. Rose, and W. H. Greene. 2005. Applied Choice Analysis: A Primer. Cambridge University Press: Cambridge UK. 717 p.

Holmes, T. P. and W. L. Adamowicz. 2003. Attribute based methods. In A Primer on Nonmarket Valuation, Champ, P. A., K. J. Boyle and T. C. Brown (eds.). Dordrecht/Boston/London: Kluwer Academic Publishers, pp. 171-219.

Horowitz, J. and K. McConnell. 2002. A Review of WTA/WTP Studies. Journal of Environmental Economics and Management44 (3): 426-447.

Kaplowitz, M. D., T. D. Hadlock, and R. Levine. 2004. A comparison of web and mail survey response rates. Public Opinion Quarterly 68(1): 94-101.

Kerkvleit, J., C. Nowell and S. Lowe. 2002. The economic value of the Greater Yellowstone's blue-ribbon fishery. North American Journal of Fisheries Management 22: 418-424

Krutilla, J. V. 1967. Conservation reconsidered. The American Economic Review 57(4): 777-786.

Leggett, C. G., N. S. Kleckner, K. J. Boyle, J. W. Duffield and R. C. Mitchell. 2003. Social desirability bias in contingent valuation surveys administered through in-person interviews. Land Economics 79(4): 561-575.

Lindhjem, H. and S. Navrud. 2011. Using internet in stated preference surveys: a review and comparison of survey modes. International Review of Environmental and Resource Economics 5: 309-351.

Loomis, J. 1996. Measuring the economic benefits of removing dams and restoring the Elwha River: Results of a contingent valuation survey. Water Resources Research 32(2): 441-447.

Loomis, J. 2005. Updated Outdoor Recreation Use Values on National Forest and Other Public Lands. USDA Forest Service, General Technical Report PNW-GTR-658. Portland, Oregon. http://www.treesearch.fs.fed.us/pubs/21052

Louviere, J. J., D. A. Hensher and J. D. Swait. 2000. Stated Choice Methods: Analysis and Application. Cambridge University Press: Cambridge UK. 402 p.

Mitchell, R. C. and R. T. Carson. 1989. Using Surveys to Value Public Good: The Contingent Valuation Method. Resources For the Future: Washington DC. 463 p.

National Research Council. 2013. Nonresponse in Social Science Surveys. National Academy Press, Washington DC.

National Park Service. n.d. National Park Service Programs: A Companion Volume to NPS Management Policies. National Park Service, Washington DC.

Neher, C., J. Duffield and D. Patterson. 2013. Valuation of National Park system visitation: the efficient use of count data models, meta-analysis, and secondary visitor survey data. Environmental Management 52(3): 683-698.

Poole, B. D. and D. K. Loomis. 2010. A comparative analysis of mail and internet surveys. In: Watts, Clifton E., Jr.; Fisher, Cherie LeBlanc, eds. Proceedings of the 2009 Northeastern Recreation 
Research Symposium. Gen. Tech. Rep. NRS-P-66. Newtown Square, PA: U.S. Department of Agriculture, Forest Service, Northern Research Station: 231-234.

Orme, B. 2010. Getting Started with Conjoint Analysis. Second Edition, Research Publishers, LLC. Madison, WI. https://www.sawtoothsoftware.com/download/techpap/samplesz.pdf

Rollins, K. and A. Lyke. 1998. The Case for Diminishing Marginal Existence Values. Journal of Environmental Economics and Management 36: 324-344.

Schulze, W. D., D. S. Brookshire, E. G. Walther, K. K. MacFarland, M. A. Thayer, R. L. Whitworth. S. Ben-David, W. Malm and John Molenar. 1983. The economic benefits of preserving visibility in the National Parklands of the Southwest. Natural Resources Journal. 23: 149-173.

Schulze, W. D., D. S. Brookshire, E. G. Walther, K. Kelley, M. A. Thayer, R. L. Whitworth, S. BenDavid, W. Maim, and J. Molenar. 1985. The Benefits of Preserving Visibility in the National Parklands of the Southwest. In: Methods Development for Environmental Control Benefits Assessment, Volume VIII. EPA-230-12-85-026. 21 pp.

Silva, A., R. M. Nayga, B. L. Campbell, and J. L. Park. 2011. Revisiting cheap talk with new evidence from a field experiment. Journal of Agricultural and Resource Economics 36(2): 280-291.

Stratus Consulting. 2015. Economic Evaluation of Restoration Actions for Salmon and Forests and Associated Wildlife in and Along the Elwha River. Boulder, CO.

Taylor, P. A., N. M. Nelson, B. D. Grandjean, B. Annatchkova, D. Aadland. 2009. Mode effects and other potential biases in panel-based internet surveys: final report. Prepared for National Center for Environmental Economics, Office of Policy, Economics, and Innovation, U.S. Environmental Protection Agency, Washington, DC. WYSAC Technical Report No. SRC-905. Laramie, WY: Wyoming Survey \& Analysis Center, University of Wyoming. 60 p.

Taylor, P.A. B.D. Grandjean and J. Gramann. 2011. National Park Service Comprehensive Survey of the American Public. Natural Resources Report NPS/NRSS/SSD/NRR—2011/432. Wyoming Survey and Analysis Center, University of Wyoming, Laramie, WY.

Thomas, C., C. Huber, and L. Koontz. 2014. 2012 National Park Visitor Spending Effects. Natural Resources Report NPS/NRSS/EQD/NRR-2014/765.

Turner, R. W. 2012. Using contingent choice surveys to inform National Park Management. Paper presented at the Association for Environmental Studies and Sciences Conference. June 21-24, 2012, Santa Clara California. 45pp.

Turner, R. W. and B. Willmarth. 2014. "Valuation of Cultural and Natural Resources in North Cascades National Park: Results from a Tournament-Style Contingent Choice Survey". Economics Faculty Working Papers. Paper 38.

U.S. Environmental Protection Agency. 2010. Guidelines for Preparing Economic Analyses. 300 pp.

U.S. Office of Management and Budget. 1992. Circular No. A-94 Revised. Memorandum for Heads of Executive Departments and Establishments, Guidelines and Discount Rates for Benefit-Cost Analysis of Federal Programs. (https://www.whitehouse.gov/omb/circulars a094/)

U.S. Water Resources Council. 1983. Economic and Environmental Principles and Guidelines for Water and Related Land Resources Implementation Studies. 137 pp.

Vossler, C. A. and M. F. Evans. 2009. Bridging the gap between the field and the lab: environmental goods, policy maker input, and consequentiality. Journal of Environmental Economics and Management 58(3):338-345. 
Walsh, R., J. Loomis and R. Gillman. 1984. Valuing Option, Existence and Bequest Demands for Wilderness. Land Economics 60(1): 14-29.

Welsh, M. P., R. C. Bishop, M. L. Phillips and R. M. Baumgartner. 1997. Glen Canyon Dam, Colorado River Storage Project, Arizona: Nonuse Values Study, Final Report. Prepared for U.S.

Department of the Interior, Bureau of Reclamation, Upper Colorado Regional Office, Salt Lake City UT Report Number EC-97-10. 382 pp.

Wyoming Survey and Analysis Center. 2013. Cost Proposal: Your National Park Service Lands and Programs. University of Wyoming, Laramie, WY. 
10. Appendix

A. Questionnaire

\section{Your National Park Service Lands \& Programs: What Do You Think?}

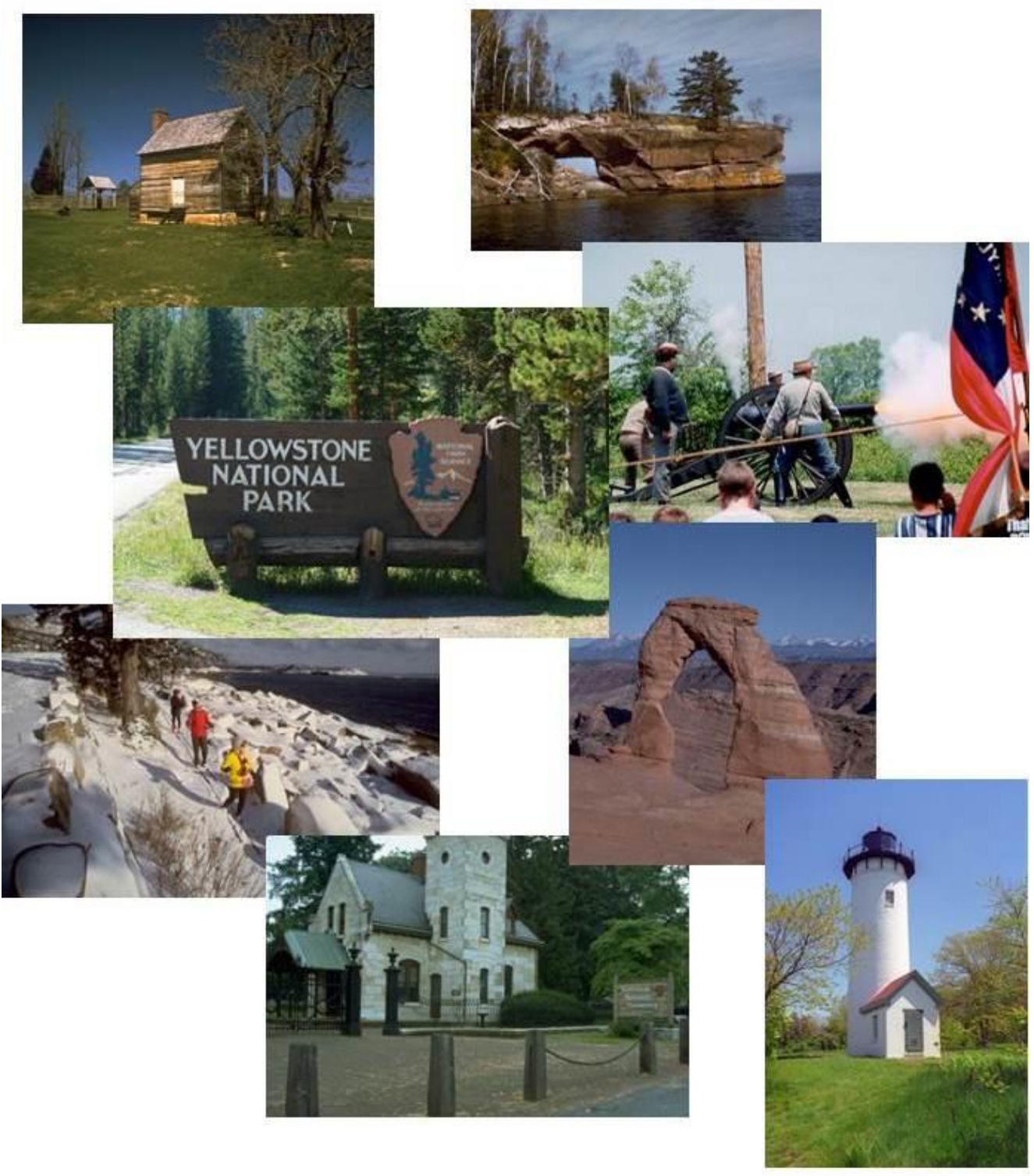

Colorado 
Colorado State University is conducting a survey on public attitudes toward the National Park Service. It is important that we hear from everyone. Your opinion is valuable even if you have not visited any National Parks or participated in any type of National Park programs.

- The first two pages contain some background information.

- The survey questions begin on page 4 .

Every state contains one or more of the $\mathbf{4 0 2}$ National Park Service areas.

The National Park Service manages three kinds of areas:

National Park areas that focus on the preservation of nature and nature-based recreation. These include:

- National Parks such as Yellowstone (WY, MT, ID) and Acadia (ME)

- some National Monuments such as Devils Tower (WY) and Cedar Breaks (UT)

- National Preserves such as Big Cypress (FL) and Tallgrass Prairie (KS)

- National Parkways such as The Blue Ridge Parkway (NC, VA) and The John D. Rockefeller Memorial Parkway (WY)

- National Scenic Trails such as The Appalachian Trail (which runs through 14 states from ME to GA).

- some National Recreation Areas such as the Santa Monica Mountains (CA) and Bighorn Canyon (MT, WY)

There are 79 million acres of National Park areas that focus on nature and nature-based recreation.

National Park areas that focus on the preservation of American history and culture or the commemoration and remembrance of significant events and people. These include:

- National Historic Sites such as Theodore Roosevelt Birthplace (NY) and The Tuskegee Airmen National Historic Site (AL)

- National Battlefields such as Antietam (MD) and Gettysburg (PA)

- National Memorials such as The Presidential memorials and the Flight 93 National Memorial (PA)

- some National Monuments such as the First State National Monument (DE) and The Statue of Liberty (NY)

There are 226 National Park areas that focus on historic preservation.

National Park areas that focus on protecting shorelines and bodies of water. These include:

- National Lakeshores on the Great Lakes such as Apostle Islands (WI) and Sleeping Bear Dunes (MI)

- National Seashores such as Padre Island (TX) and Point Reyes (CA)

- National Rivers such as The Rio Grande Wild \& Scenic River (TX) and The Mississippi National River \& Recreation Area $(\mathrm{MN})$

- some National Recreation Areas such as Lake Mead (AZ, NV) and Lake Meredith (TX)

There are 4.8 million acres of National Park areas that focus on protecting shorelines and bodies of water. 
The National Park Service also provides many programs outside of the National Parks, in communities in every state.

\section{These programs have several purposes, including:}

Preservation of local historic buildings and sites which commemorate American history and culture or significant events and people.

These programs provide assistance to residents and communities wishing to protect local historic sites and buildings outside of the National Parks. This includes:

- Providing grants for historic preservation

- Giving advice on preservation

- Administering tax credits for renovation and preservation of historic sites

- Maintaining the National Register of Historic Places

- Protect sites on the Underground Railroad,

- Protecting lighthouses and historic battlefields which are outside of National Parks

Each year these programs result in the protection of 2,000 historic sites and buildings (outside of National Parks) in communities throughout the country.

\section{Creation and improvement of recreation opportunities for communities.}

These programs help communities provide recreation facilities such as community parks, trails and open spaces through:

- Coordination and planning

- Helping to transfer other (non-National Park) federal lands to local communities for recreation areas.

Each year these programs help to transfer 2,700 acres of land to communities for parks, trails, open spaces and other recreational amenities.

\section{Protection of natural environments and features which are important to communities.}

The National Park Service works with local communities and landowners to protect local ecological, biological or geological features such as:

- Unusual landscapes

- Rock formations

- Waterfalls

- Geothermal pools

Each year these programs help designate 114 sites in communities.

Educational programs which help children and adults learn about historical, cultural and environmental topic. This includes:

- Producing educational materials for use in classrooms

- Helping bring students to parks and historical sites

- Training teachers to use historic sites and other areas in their lessons

- Training state and local professionals in historic restoration, preservation and renovation.

Each year these programs enable 4.1 million school children to attend educational programs about nature and history. 
Please check the box which best describes how you feel about the statements below.

$\begin{array}{lcccc} & \begin{array}{c}\text { Strongly } \\ \text { disagree }\end{array} & \text { Disagree } & \begin{array}{c}\text { Neither } \\ \text { agree nor } \\ \text { disagree }\end{array} & \begin{array}{c}\text { Strongly } \\ \text { Agree }\end{array} \\ \begin{array}{l}\text { 1. It is important to me that historic sites are protected } \\ \text { for current and future generations whether I visit } \\ \text { them or not. }\end{array} & \square & \square & \square & \square \\ \end{array}$

2. National Park areas are good places to bring children to learn about nature.

3. Local governments do not need any help from the National Park Service to protect local historic sites and buildings.

4. I enjoy visiting historic sites and buildings.

5. The U.S. should sell off some National Parks.

6. Local governments should be able to provide trails, parks and open spaces in communities without the help of the National Park Service.

7. I enjoy using local trails, parks and open spaces in my community and in other places.

8. I do not benefit directly from National Parks.

9. Private businesses could probably do a better job than the federal government at protecting local historic sites and buildings.

10. It is important to me that trails, parks, and open spaces in communities are protected for current and future generations, whether I use them or not.

11. National Parks are important to me because I enjoy visiting them.

12. It is important to me that National Parks are preserved for current and future generations whether I visit them or not. 
The federal government is running a large deficit and is considering selling some National Park areas (described on page 2) and cutting some National Park Service programs (described on page 3) to save money.

- National Park areas sold to private landowners would no longer have the current level of public access. These lands may be developed for houses, offices, resorts or other developments. They may also be used for timber harvesting, oil and gas development or mining.

- Some land in all National Park areas in every state would potentially be sold.

- Program cuts would potentially apply to all types of programs and would be spread across every state.

One proposal to avoid the sale of National Park areas and cuts to the National Park Service facilitated programs is to set up a special fund dedicated to the National Park Service.

- The dedicated fund would be paid for by an increase in the federal income tax.

- The increase would be paid annually and would last for 10 years.

- All U.S. households would pay the tax.

On the next page you will be asked to decide whether you would choose to raise taxes to avoid selling National Park areas and cutting National Park Service programs.

- Your answers will be used to help the federal government compare the cost of the National Park Service with the benefits to American households. The answers you give could affect the amount of National Park areas and National Park Service programs available in the future and the amount of taxes you pay.

- In making this decision, please take into account your household income, whether you can afford to make the payment shown, and whether National Park areas and National Park Service community programs are worth that much to you.

- Consider everything else you could buy with the money and whether there are other government programs that you might rather see money spent on.

You will be asked two separate questions, one on National Park areas and another on National Park Service facilitated programs. Please consider the combined cost for the two questions when giving your answer. 
OPTIONS FOR NATIONAL PARK AREAS

Options A and B are proposals to sell land in some or all of each type of National Park area.

Option C would retain all current National Park areas.

The option chosen by a majority of households will be carried out, and all households will pay the amount specified. There is no right or wrong answer, please choose the option that is best for you.

At the bottom of this table, please check the boxes to indicate your most preferred option and your least preferred option:

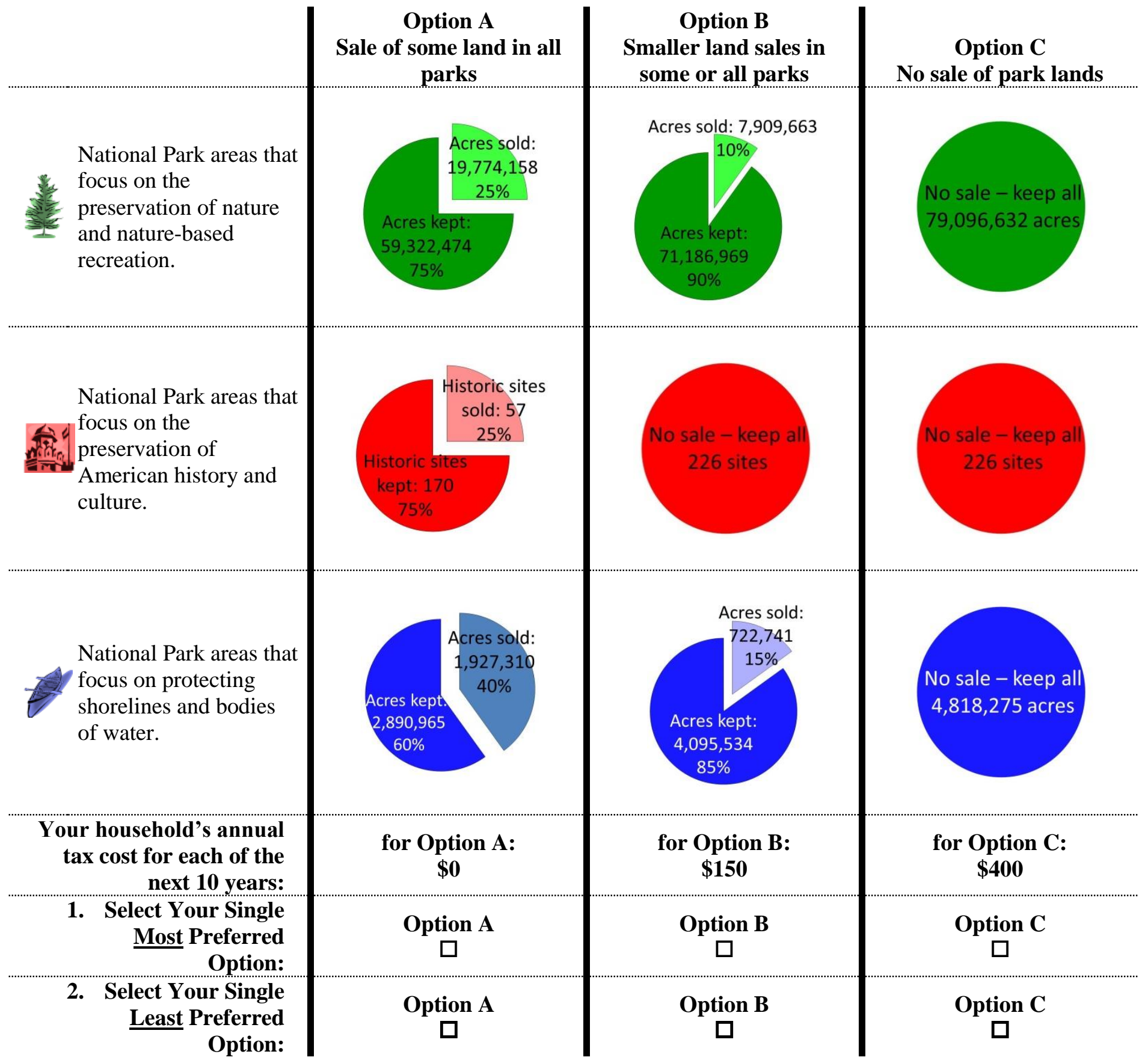


3. If there were only two choices regarding the sale of National Park areas: Option A (selling parts of all types of National Park areas) or Option C (retaining all current National Park areas) as described above where your household would have to pay an annual tax of $\$ 400$ for ten years, would you choose Option C?

\section{Yes $\quad \square \quad$ No}

4. On a scale from 1 to 10 , where 1 is "very uncertain" and 10 is "very certain," please circle the number that best describes how certain you are that you would actually choose the option you checked in question 3 (above) if you actually had to pay.

\begin{tabular}{|cccccccccc|}
\hline \multicolumn{2}{|l}{$\begin{array}{l}\text { Very uncertain } \\
1\end{array}$} & 2 & 3 & 4 & 5 & 6 & 7 & 8 & 9 \\
\hline
\end{tabular}

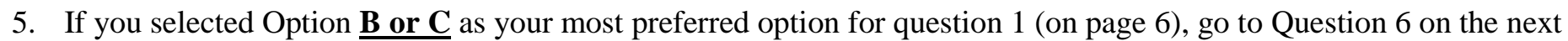
page. If you selected Option $\underline{\mathbf{A}}$ as your most preferred option please tell us why (check the single most important reason).

$\square$ National Park areas are not worth that much to me.

$\square$ I can't afford to pay that much.

$\square$ We need to cut all government spending so we can reduce the federal deficit.

$\square$ Taxes are too high already.

$\square$ Only the people who use National Park areas should have to pay for them.

$\square$ National Park areas should be paid for with existing tax dollars.

$\square$ Other (please describe): 


\section{OPTIONS FOR PROGRAMS IN COMMUNITIES}

Options D and $\mathbf{E}$ are proposals to make cuts or reductions to some or all types of programs in local communities.

Option F would keep all programs in local communities at their current levels.

The option chosen by a majority of households will be carried out, and all households will pay the amount specified. There is no right or wrong answer, please choose the option that is best for you.

At the bottom of this table, please check the boxes to indicate your most preferred option and your least preferred option:

\begin{tabular}{|c|c|c|c|}
\hline & $\begin{array}{c}\text { Option D } \\
\text { Cuts to all programs }\end{array}$ & $\begin{array}{c}\text { Option } \mathrm{E} \\
\text { Smaller cuts to some or all } \\
\text { programs }\end{array}$ & $\begin{array}{c}\text { Option } F \\
\text { No cuts to programs }\end{array}$ \\
\hline $\begin{array}{l}\text { Additional local historic } \\
\text { sites and buildings } \\
\text { outside of National } \\
\text { Parks protected each } \\
\text { year. }\end{array}$ & $\begin{array}{c}\text { Sites left } \\
\text { unprotected } \\
\text { each year: } 600 \\
30 \%\end{array}$ & $\begin{array}{c}\text { Sites left unprotected } \\
\text { each year: } 400 \\
20 \% \\
\text { ites protected each } \\
\text { year: } 1,600\end{array}$ & ted \\
\hline $\begin{array}{l}\text { Additional non-National } \\
\text { Park acres transferred to } \\
\text { communities for } \\
\text { recreation each year. }\end{array}$ & $\begin{array}{l}\text { Eligible acres not } \\
\text { transferred each } \\
\text { year: } 1,080 \\
\quad 40 \% \\
\text { ferred } \\
1,620\end{array}$ & $\begin{array}{l}\text { acres } \\
\text { sferred } \\
\text { ar: } 945 \\
\%\end{array}$ & \\
\hline $\begin{array}{l}\text { Natural areas which are } \\
\text { communities protected } \\
\text { each year. }\end{array}$ & $\begin{array}{c}\text { Eligible areas left } \\
\text { unprotected each } \\
\text { year: } 23 \\
20 \% \\
\text { Areas } \\
\text { protected } \\
\text { each year: } 91 \\
80 \%\end{array}$ & $\begin{array}{c}\begin{array}{c}\text { Eligible areas left } \\
\text { unprotected each } \\
\text { year: } 23 \\
20 \% \\
\text { Areas } \\
\text { protected } \\
\text { each year: } 91 \\
80 \%\end{array}\end{array}$ & $\begin{array}{l}\text { No cuts }-114 \text { natural } \\
\text { areas which are important } \\
\text { to local communities } \\
\text { protected each year }\end{array}$ \\
\hline $\begin{array}{l}\text { Number of school } \\
\text { children who attend } \\
\text { educational programs } \\
\text { produced by the } \\
\text { National Park Service } \\
\text { each year. }\end{array}$ & $\begin{array}{r}\text { School children } \\
\text { not served each } \\
\text { year: } 1,230,000 \\
30 \% \\
\text { School children } \\
\text { served each year: } \\
2,870,000 \\
70 \%\end{array}$ & $\begin{array}{c}\text { School children not } \\
\text { served each year: } \\
410,000 \\
10 \% \\
\text { School children } \\
\text { served each } \\
\text { year: } 3,690,000 \\
90 \%\end{array}$ & $\begin{array}{l}\text { villion } \\
\text { attend } \\
\text { grams }\end{array}$ \\
\hline $\begin{array}{r}\text { Your household's annual } \\
\text { tax cost for each of the next } \\
10 \text { years }\end{array}$ & for Option D: $\$ 0$ & $\begin{array}{l}\text { for Option E: } \\
\qquad 60\end{array}$ & $\begin{array}{l}\text { for Option } F: \\
\$ 100\end{array}$ \\
\hline $\begin{array}{l}\text { 6. Select Your Single Most } \\
\text { Preferred Option: }\end{array}$ & Option D & Option E & Option F \\
\hline $\begin{array}{l}\text { 7. Select Your Single } \\
\text { Least Preferred Option: }\end{array}$ & $\begin{array}{c}\text { Option D } \\
\square\end{array}$ & $\begin{array}{c}\text { Option E } \\
\square\end{array}$ & $\begin{array}{c}\text { Option F } \\
\square\end{array}$ \\
\hline
\end{tabular}


8. If there were only two choices regarding cutting National Park Service programs: Option D (the reduction of all National Park Service programs) or Option F (retain all current National Park Service programs) as described above where your household would have to pay an annual tax of $\$ 100$ for ten years, would you choose Option F?

Yes $\quad \square \quad$ No

9. On a scale from 1 to 10 , where 1 is "very uncertain" and 10 is "very certain," please circle the number that best describes how certain you are that you would actually choose the option you checked in question 8 (above) if you actually had to pay.

\begin{tabular}{|cccccccccc|}
\hline \multicolumn{2}{|l}{$\begin{array}{l}\text { Very uncertain } \\
1\end{array}$} & 2 & 3 & 4 & 5 & 6 & 7 & 8 & 9 \\
\hline
\end{tabular}

10. If you selected Option $\underline{\mathbf{E} \text { or } \mathbf{F}}$ as your most preferred option for question 6 (on page 8) go to Question 11 . If you selected Option $\underline{\mathbf{D}}$ as your most preferred option please tell us why (check the single most important reason).

$\square$ National Park Service programs are not worth that much to me.

$\square$ I can't afford to pay that much.

$\square$ We need to cut all government spending so we can reduce the federal deficit.

$\square$ Taxes are too high already.

$\square$ Only the people who use National Park Service programs should have to pay for them.

$\square$ National Park Service programs should be paid for with existing tax dollars.

$\square$ Other (please describe):

11. How certain are you that your answers would be used by the federal government to decide whether to sell National Park areas and/or to cut National Park Service programs?
Very certain
Certain
Neither certain nor
uncertain
Uncertain
Very uncertain

12. How certain are you that you would actually have to pay the tax increase to avoid the sale of National Park areas and/or the cuts to National Park Service Programs?

$\square$ Very certain $\quad \square$ Certain $\quad \square \begin{aligned} & \text { Neither certain nor } \\ & \text { uncertain }\end{aligned}$ Uncertain $\quad \square$ Very uncertain


Next, we would like to know about you and your recreational activities. Your answers to these questions will only be used to see how well our survey sample represents the American public as a whole. Your answers are confidential. You will not be identified in any way.

1. In the last 2 years have you participated in any outdoor activities anywhere, not just in the National Parks? (Check all that apply.)

Visited a beach, a lake or a reservoir

Watched birds or other wildlife

Visited local historic sites

Visited local natural areas where ecological or geological amenities are featured.
Gone hiking

Gone camping

Visited local open spaces, trails or parks

Participated in local natural or historical education programs

Other outdoor activities (please describe)

2. In total, how often did you do all of the activities you checked above in the last 2 years?
1 to 3 times
4 to 5 times
6 to 9 times
10 to 19 times
20 or more times

3. Have you visited any of National Park areas anywhere in the U.S. in the past 2 years?
Yes

\section{No $\rightarrow$ If No please skip Questions 4 and 5.}

4. Which types of National Park areas you have visited in the last 2 years (check all that apply):

National Park areas that focus on the preservation of nature and nature-based recreation.

(National Parks, some National Monuments, National Preserves, National Parkways, National Scenic

Trails, and some National Recreation Areas)

National Park areas that focus on the preservation of American history and culture or the commemoration and remembrance of significant events and people.

(National Historic Sites, National Battlefields, National Memorials, and some National Monuments)

\section{National Park areas that focus on protecting shorelines and bodies of water.}

(National Lakeshores on the Great Lakes, National Seashores, National Rivers, and some National Recreation Areas)

5. In total, how often did you visit any type of National Park area in the last 2 years?

$\square 1$ to 3 times

$\square 4$ to 5 times

6 to 9 times

10 or more times

6. Do you belong to any local, state or national organizations whose main purpose is to protect National Parks or other federal public lands?
Yes
No 
7. What is your zip code?

8. Are you: $\square$ Male $\square$ Female

9. In what year were you born?

10. Are you retired?

Yes

No

11. How would you describe your overall political point of view?
Mostly Democratic
Leaning Republican
Completely independent
Leaning Democratic
Mostly Republican
Not sure

12. What is the highest level of school you have completed

Some high school

Some college or technical school (but no degree)

Bachelor's degree (BA, BS, AB, etc.)

Doctoral degree $(\mathrm{PhD}, \mathrm{EdD}$, etc.)
High school graduate or equivalent

Associate's degree (including occupational or academic degrees)

$\square \quad$ Master's degree (MA, MS, MENG, MSW, etc.)

$\square \quad$ Professional school degree (MD, DDC, JD, etc.)

13. Here is a list of racial categories. Please select one or more which best describes your race:
American Indian or Alaska
Native Hawaiian or other
Native
Pacific Islander
Asian
Black or African American
White
Other

14. Are you Hispanic or Latino?

Yes

$\square \quad$ No

15. Next we'd like to ask you about your household income. Your answer will be kept strictly confidential, and only used for comparing groups of people. Which of the following income categories best describes your household's total income in 2012, before taxes?
$\square$ Less than $\$ 15,000$
$\$ 15,000$ up to $\$ 24,999$
$\$ 25,000$ up to $\$ 34,999$
$\square \$ 35,000$ up to $\$ 49,999$
$\$ 50,000$ up to $\$ 74,999$
$\$ 75,000$ up to $\$ 99,999$
$\square \$ 100,000$ up to $\$ 149,999$
$\$ 150,000$ up to $\$ 199,999$
$\square \$ 200,000$ or more

16. What is the total number of people who contribute to the household income noted above?

17. How many children under the age of 18 are in your household? (number) 
Thank you for taking time to help us out with this project. Do you have any additional comments you would like to add?

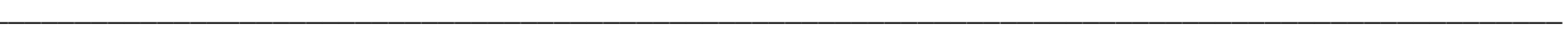




\section{B. Additional Models}

This section compares the results of the rank-ordered logistic regression and the marginal and total value calculations for all of the models which we estimated in the course of analyzing this data. The first two tables compare the seven regression models for parks (Table B1) and six regression models for programs (Table B2). The second two tables (Tables B3 and B4) show the estimated marginal and total values for all of the parks models and programs models respectively.

Table B1. Comparison of Rank-ordered Logit Models for National Parks

\begin{tabular}{|c|c|c|c|c|c|}
\hline & & $\begin{array}{l}\text { Nature-focused } \\
\text { NPS acres }\end{array}$ & $\begin{array}{c}\text { History-focused } \\
\text { NPS sites }\end{array}$ & $\begin{array}{l}\text { Water-focused } \\
\text { NPS acres }\end{array}$ & $\begin{array}{c}\text { Annual cost of } \\
\text { option (tax) }\end{array}$ \\
\hline $\begin{array}{l}\text { 1. Base Model-no } \\
\text { weights }\end{array}$ & $\begin{array}{l}\text { Coefficient } \\
\text { (Std. Error) }\end{array}$ & $\begin{array}{c}2.93 \mathrm{E}-08 * * * \\
(7.74 \mathrm{E}-09)\end{array}$ & $\begin{array}{c}0.0074264 * * * \\
(0.00221)\end{array}$ & $\begin{array}{c}\text { 4.41E-07 *** } \\
(1.22 \mathrm{E}-07)\end{array}$ & $\begin{array}{c}-0.0017935^{* * *} * \\
(0.0002913)\end{array}$ \\
\hline $\begin{array}{l}\text { 2. Weighted for } \\
\text { demographics }\end{array}$ & $\begin{array}{l}\text { Coefficient } \\
\text { (Std. Error) }\end{array}$ & $\begin{array}{c}2.48 \mathrm{E}-08 * * \\
(9.56 \mathrm{E}-09)\end{array}$ & $\begin{array}{c}0.0052674 * * \\
(0.0025794)\end{array}$ & $\begin{array}{c}0.00000038 * * \\
(1.68 \mathrm{E}-07)\end{array}$ & $\begin{array}{c}-0.0011557 * * * \\
(0.0004327)\end{array}$ \\
\hline $\begin{array}{l}\text { 3. Weighted for } \\
\text { National Park } \\
\text { visitation }\end{array}$ & $\begin{array}{l}\text { Coefficient } \\
\text { (Std. Error) }\end{array}$ & $\begin{array}{c}2.49 \mathrm{E}-08 * * * \\
(6.99 \mathrm{E}-09)\end{array}$ & $\begin{array}{c}0.0068598 * * * \\
(0.0017039)\end{array}$ & $\begin{array}{c}0.00000036 \text { *** } \\
\quad(1.14 \mathrm{E}-07)\end{array}$ & $\begin{array}{c}-0.0017724 * * * \\
(0.0002924)\end{array}$ \\
\hline $\begin{array}{l}\text { 4. Weighted for } \\
\text { demographics \& } \\
\text { Park visitation }\end{array}$ & $\begin{array}{l}\text { Coefficient } \\
\text { (Std. Error) }\end{array}$ & $\begin{array}{c}2.1 \mathrm{E}-08 * * \\
(9.5 \mathrm{E}-09)\end{array}$ & $\begin{array}{c}0.0063523 * * \\
(0.0029127)\end{array}$ & $\begin{array}{l}0.00000037 * * \\
\quad(1.71 \mathrm{E}-07)\end{array}$ & $\begin{array}{c}-0.0015292 * * * \\
(0.0004411)\end{array}$ \\
\hline $\begin{array}{l}\text { 5. National Park } \\
\text { Visitors only }\end{array}$ & $\begin{array}{l}\text { Coefficient } \\
\text { (Std. Error) }\end{array}$ & $\begin{array}{c}3.12 \mathrm{E}-08 * * * \\
(1.07 \mathrm{E}-08)\end{array}$ & $\begin{array}{c}0.0079144 * * * \\
(0.002971)\end{array}$ & $\begin{array}{c}5.69 \mathrm{E}-07 * * * \\
(1.69 \mathrm{E}-07)\end{array}$ & $\begin{array}{c}-0.00116 * * * \\
(0.0003724)\end{array}$ \\
\hline 6. Non-visitors & $\begin{array}{l}\text { Coefficient } \\
\text { (Std. Error) }\end{array}$ & $\begin{array}{c}2.89 \mathrm{E}-08 * * \\
(1.20 \mathrm{E}-08)\end{array}$ & $\begin{array}{c}0.0081252 * * \\
(0.0035738)\end{array}$ & $\begin{array}{c}2.19 \mathrm{E}-07 \\
(1.90 \mathrm{E}-07)\end{array}$ & $\begin{array}{c}-0.0027344 * * * \\
(0.0005022)\end{array}$ \\
\hline $\begin{array}{l}\text { 7. Nature \& water } \\
\text { parks combined }\end{array}$ & $\begin{array}{l}\text { Coefficient } \\
\text { (Std. Error) }\end{array}$ & $\begin{array}{c}4.62 \mathrm{E}-08 * * * \\
(5.87 \mathrm{E}-09)\end{array}$ & $\begin{array}{c}0.0104382 * * * \\
(0.0019831)\end{array}$ & $\begin{array}{c}\text { (Nature-and } \\
\text { water-focused } \\
\text { parks combined) }\end{array}$ & $\begin{array}{c}-0.0018211 * * * \\
(0.0002919)\end{array}$ \\
\hline
\end{tabular}

* Significant at .9, ** Significant at .95, *** Significant at .99

Dependent variable $=$ Rank of National Park policy option 
Table B2. Comparison of Rank-ordered Logit Models for NPS Programs

\begin{tabular}{|c|c|c|c|c|c|c|}
\hline & & $\begin{array}{c}\text { Historic sites } \\
\text { and buildings } \\
\text { protected }\end{array}$ & $\begin{array}{c}\text { Acres } \\
\text { transferred to } \\
\text { communities }\end{array}$ & $\begin{array}{c}\text { Natural } \\
\text { landmarks } \\
\text { protected }\end{array}$ & $\begin{array}{c}\text { Number served } \\
\text { by NPS educ. } \\
\text { programs }\end{array}$ & $\begin{array}{c}\text { Annual cost of } \\
\text { option (tax) }\end{array}$ \\
\hline $\begin{array}{l}\text { 1. Base Model-no } \\
\text { weights }\end{array}$ & $\begin{array}{l}\text { Coefficient } \\
\text { ( Std. } \\
\text { Error) }\end{array}$ & $\begin{array}{c}0.000521 \\
(0.000327)\end{array}$ & $\begin{array}{c}0.000247 \\
(0.000215)\end{array}$ & $\begin{array}{c}0.012303 * * \\
(0.005887)\end{array}$ & $\begin{array}{c}8.17 \mathrm{E}-07 * * * \\
(1.27 \mathrm{E}-07)\end{array}$ & $\begin{array}{c}-0.00412 * * * \\
(0.000359)\end{array}$ \\
\hline $\begin{array}{l}\text { 2. Weighted for } \\
\text { demographics }\end{array}$ & $\begin{array}{l}\text { Coefficient } \\
\text { ( Std. } \\
\text { Error) }\end{array}$ & $\begin{array}{c}0.001399 * * * \\
(0.000438)\end{array}$ & $\begin{array}{c}0.000175 \\
(0.000321)\end{array}$ & $\begin{array}{c}0.007829 \\
(0.007028)\end{array}$ & $\begin{array}{c}\text { 7.23E-07 *** } \\
(1.58 \mathrm{E}-07)\end{array}$ & $\begin{array}{c}-0.00437 * * * \\
(0.000472)\end{array}$ \\
\hline $\begin{array}{l}\text { 3. Weighted for } \\
\text { National Park } \\
\text { visitation }\end{array}$ & $\begin{array}{l}\text { Coefficient } \\
\text { ( Std. } \\
\text { Error) }\end{array}$ & $\begin{array}{c}0.000657 * * \\
(0.000289)\end{array}$ & $\begin{array}{c}0.000151 \\
(0.000201)\end{array}$ & $\begin{array}{c}0.012672 * * \\
(0.005137)\end{array}$ & $\begin{array}{c}6.91 \mathrm{E}-07 * * * \\
(1.09 \mathrm{E}-07)\end{array}$ & $\begin{array}{c}-0.00415 * * * \\
(0.000324)\end{array}$ \\
\hline $\begin{array}{l}\text { 4. Weighted for } \\
\text { demog. \& Park } \\
\text { visitation }\end{array}$ & $\begin{array}{l}\text { Coefficient } \\
\text { ( Std. } \\
\text { Error) }\end{array}$ & $\begin{array}{c}0.001502 * * * \\
(0.000435)\end{array}$ & $\begin{array}{c}0.000189 \\
(0.000324)\end{array}$ & $\begin{array}{c}0.009658 \\
(0.007458)\end{array}$ & $\begin{array}{c}6.28 \mathrm{E}-07 * * * \\
(1.73 \mathrm{E}-07)\end{array}$ & $\begin{array}{c}-0.00461 * * * \\
(0.000475)\end{array}$ \\
\hline $\begin{array}{l}\text { 5. National Park } \\
\text { Visitors only }\end{array}$ & $\begin{array}{l}\text { Coefficient } \\
\text { ( Std. } \\
\text { Error) }\end{array}$ & $\begin{array}{c}0.000167 \\
(0.000423)\end{array}$ & $\begin{array}{l}0.00057 * * \\
(0.000285)\end{array}$ & $\begin{array}{c}0.009433 \\
(0.007923)\end{array}$ & $\begin{array}{c}9.94 \mathrm{E}-07 * * * \\
(1.66 \mathrm{E}-07)\end{array}$ & $\begin{array}{c}-0.0035 * * * \\
(0.000446)\end{array}$ \\
\hline 6. Non-visitors & $\begin{array}{l}\text { Coefficient } \\
\text { ( Std. } \\
\text { Error) }\end{array}$ & $\begin{array}{c}0.001057 * * \\
(0.000555)\end{array}$ & $\begin{array}{l}7.75 \mathrm{E}-05 \\
(0.000355)\end{array}$ & $\begin{array}{c}0.020001 * * \\
(0.009356)\end{array}$ & $\begin{array}{l}\text { 4.43E-07 ** } \\
\quad(2.2 \mathrm{E}-07)\end{array}$ & $\begin{array}{c}-0.00565 * * * \\
(0.000655)\end{array}$ \\
\hline
\end{tabular}

* Significant at .9, ** Significant at .95, *** Significant at .99

Dependent variable $=$ Rank of NPS Program policy option 
Table B3. Calculated Marginal and Total Values for All Parks Models

\begin{tabular}{|c|c|c|c|c|c|c|c|c|c|c|c|}
\hline & \multicolumn{3}{|c|}{ Nature-focused Parks } & \multicolumn{3}{|c|}{ History-focused Parks } & \multicolumn{3}{|c|}{ Water-focused Parks } & \multirow{2}{*}{\multicolumn{2}{|c|}{$\begin{array}{c}\text { All Parks } \\
\text { Total Value }\end{array}$}} \\
\hline & \multirow{2}{*}{$\begin{array}{l}\text { Marg. Val. } \\
\text { \$/acre } \\
\text { (95\% Conf. } \\
\text { Int.) }\end{array}$} & \multirow{2}{*}{\multicolumn{2}{|c|}{\begin{tabular}{cc}
\multicolumn{2}{c}{ Total Value } \\
$\$$ for cuts \\
avoided & $\$$ all acres \\
(95\% Conf. & (95\% Conf. \\
Int.) & Int.) \\
\end{tabular}}} & \multirow{2}{*}{$\begin{array}{l}\text { Marg. Val. } \\
\text { \$/site } \\
\text { (95\% Conf. } \\
\text { Int.) }\end{array}$} & \multirow{2}{*}{\multicolumn{2}{|c|}{ 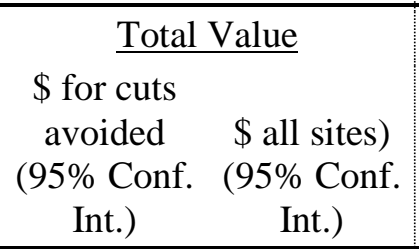 }} & \multirow{2}{*}{$\begin{array}{l}\text { Marg. Val. } \\
\text { \$/acre } \\
\text { (95\% Conf. } \\
\text { Int.) }\end{array}$} & \multirow{2}{*}{\multicolumn{2}{|c|}{\begin{tabular}{lc}
\multicolumn{2}{c}{ Total Value } \\
$\$$ for cuts \\
avoided & $\$$ all acres \\
(95\% Conf. & (95\% Conf. \\
Int.) & Int.)
\end{tabular}}} & & \\
\hline & & & & & & & & & & $\begin{array}{c}\$ \text { for cuts } \\
\text { avoided } \\
\text { (95\% Conf. } \\
\text { Int.) }\end{array}$ & $\begin{array}{c}\$ \text { all } \\
\text { acres/sites } \\
(95 \% \text { Conf. } \\
\text { Int.) }\end{array}$ \\
\hline $\begin{array}{l}\text { 1. Base } \\
\text { Model-no } \\
\text { weights }\end{array}$ & $\begin{array}{l}1.64 \mathrm{e}^{-5} \\
\left(8.02 \mathrm{e}^{6}-\right. \\
\left.2.47 \mathrm{e}^{5}\right)\end{array}$ & $\begin{array}{c}220 \\
(109-331)\end{array}$ & $\begin{array}{c}1,294 \\
(639-1,950)\end{array}$ & $\begin{array}{c}4.14 \\
(1.52-6.76)\end{array}$ & $\begin{array}{c}159 \\
(58-260)\end{array}$ & $\begin{array}{c}936 \\
(343-1,528)\end{array}$ & $\begin{array}{c}2.46 \mathrm{e}^{-4} \\
\left(9.19 \mathrm{e}^{-5}-\right. \\
\left.4.00 \mathrm{e}^{-4}\right)\end{array}$ & $\begin{array}{c}225 \\
(84-366)\end{array}$ & $\begin{array}{c}1,184 \\
(443-1,926)\end{array}$ & $\begin{array}{c}604 \\
(451-758)\end{array}$ & $\begin{array}{c}3,414 \\
(2,554- \\
4,275)\end{array}$ \\
\hline $\begin{array}{l}\text { 2. Weighted } \\
\text { for demog. }\end{array}$ & $\begin{array}{l}2.14 \mathrm{e}^{-5} \\
\left(2.73 \mathrm{e}^{-6}\right. \\
\left.4.01 \mathrm{e}^{-5}\right)\end{array}$ & $\begin{array}{c}288 \\
(45-532)\end{array}$ & $\begin{array}{c}1,695 \\
(262-3,128)\end{array}$ & $\begin{array}{c}4.56 \\
(-0.11-9.23)\end{array}$ & $\begin{array}{c}175.07 \\
(-4.24-354)\end{array}$ & $\begin{array}{c}1,030 \\
(-25-2,085)\end{array}$ & $\begin{array}{l}3.29 \mathrm{e}^{-4} \\
\left(-6.1 \mathrm{e}^{-5}-\right. \\
\left.7.19 \mathrm{e}^{-4}\right)\end{array}$ & $\begin{array}{c}301 \\
(-56-658)\end{array}$ & $\begin{array}{c}1,584 \\
(-295-3,462\end{array}$ & $\begin{array}{c}764 \\
(289-1239)\end{array}$ & $\begin{array}{c}4,309 \\
(1,666- \\
6,951)\end{array}$ \\
\hline $\begin{array}{l}\text { 3. Weighted } \\
\text { for National } \\
\text { Park } \\
\text { visitation }\end{array}$ & $\begin{array}{l}1.41 \mathrm{e}^{-5} \\
\left(6.03 \mathrm{e}^{6}-\right. \\
\left.2.21 \mathrm{e}^{5}\right)\end{array}$ & $\begin{array}{c}189 \\
(84-295)\end{array}$ & $\begin{array}{c}1,113 \\
(492-1,735)\end{array}$ & $\begin{array}{c}3.87 \\
(1.74-6.00)\end{array}$ & $\begin{array}{c}149 \\
(67-231)\end{array}$ & $\begin{array}{c}875 \\
(393-1,357)\end{array}$ & $\begin{array}{c}2.03 \mathrm{e}^{-4} \\
\left(5.99 \mathrm{e}^{-5}-\right. \\
\left.3.46 \mathrm{e}^{-4}\right)\end{array}$ & $\begin{array}{c}186 \\
(55-317)\end{array}$ & $\begin{array}{c}978 \\
(289-1,667)\end{array}$ & $\begin{array}{c}524 \\
(378-670)\end{array}$ & $\begin{array}{c}2,966 \\
(2,144- \\
3,787)\end{array}$ \\
\hline $\begin{array}{l}\text { 4. Weighted } \\
\text { for demog. } \\
\text { \& Park } \\
\text { visitation }\end{array}$ & $\begin{array}{l}1.37 \mathrm{e}^{-5} \\
\left(1.19 \mathrm{e}^{6}-\right. \\
\left.2.63 \mathrm{e}^{5}\right)\end{array}$ & $\begin{array}{c}185 \\
(18-352)\end{array}$ & $\begin{array}{c}1,086 \\
(104-2,068)\end{array}$ & $\begin{array}{c}4.15 \\
(0.31-8.00)\end{array}$ & $\begin{array}{c}160 \\
(11.90-307)\end{array}$ & $\begin{array}{c}939 \\
(70-1,808)\end{array}$ & $\begin{array}{l}2.42 \mathrm{e}^{-4} \\
\left(-2.2 \mathrm{e}^{-5}-\right. \\
\left.5.06 \mathrm{e}^{-4}\right)\end{array}$ & $\begin{array}{c}222 \\
(-21-464)\end{array}$ & $\begin{array}{c}1,165 \\
(-108-2,438)\end{array}$ & $\begin{array}{c}566 \\
(304-828)\end{array}$ & $\begin{array}{c}3,189 \\
(1,728- \\
4,651)\end{array}$ \\
\hline $\begin{array}{l}\text { 5. National } \\
\text { Park } \\
\text { Visitors only }\end{array}$ & $\begin{array}{l}2.69 \mathrm{e}^{-5} \\
\left(5.98 \mathrm{e}^{-6}-\right. \\
\left.4.78 \mathrm{e}^{-5}\right)\end{array}$ & $\begin{array}{c}361 \\
(82-641)\end{array}$ & $\begin{array}{c}2,126 \\
(483-3,770)\end{array}$ & $\begin{array}{c}6.82 \\
(0.62-13.03)\end{array}$ & $\begin{array}{c}262 \\
(24-500)\end{array}$ & $\begin{array}{c}1,542 \\
(139-2,945)\end{array}$ & $\begin{array}{l}4.90 \mathrm{e}^{-4} \\
\left(7.39 \mathrm{e}^{-5}-\right. \\
\left.9.07 \mathrm{e}^{-4}\right)\end{array}$ & $\begin{array}{c}449 \\
(68-831)\end{array}$ & $\begin{array}{c}2,363 \\
(356-4,370)\end{array}$ & $\begin{array}{c}1,073 \\
(484-1,662)\end{array}$ & $\begin{array}{c}6,031 \\
(2,738- \\
9,325)\end{array}$ \\
\hline $\begin{array}{l}\text { 6. Non- } \\
\text { visitors }\end{array}$ & $\begin{array}{c}1.06 \mathrm{e}^{-5} \\
\left(2.61 \mathrm{e}^{-6}-\right. \\
\left.1.85 \mathrm{e}^{-5}\right)\end{array}$ & $\begin{array}{c}142 \\
(35-249)\end{array}$ & $\begin{array}{c}835 \\
(207-1,463)\end{array}$ & $\begin{array}{c}2.97 \\
(0.29-5.65)\end{array}$ & $\begin{array}{c}114 \\
(11.14-217)\end{array}$ & $\begin{array}{c}672 \\
(66-1,278)\end{array}$ & $\begin{array}{l}8.01 \mathrm{e}^{-5} \\
\left(-5.9 \mathrm{e}^{-5}-\right. \\
\left.2.20 \mathrm{e}^{-4}\right)\end{array}$ & $\begin{array}{c}73 \\
(-54-201)\end{array}$ & $\begin{array}{c}386 \\
(-285-1,058)\end{array}$ & $\begin{array}{c}329 \\
(246-413)\end{array}$ & $\begin{array}{c}1,893 \\
(1,412- \\
2,373)\end{array}$ \\
\hline $\begin{array}{l}\text { 7. Nature \& } \\
\text { water parks } \\
\text { combined }\end{array}$ & $\begin{array}{l}2.54 \mathrm{e}^{-5} \\
\left(1.74 \mathrm{e}^{-5}-\right. \\
\left.3.34 \mathrm{e}^{-5}\right)\end{array}$ & $\begin{array}{c}365 \\
(254-475)\end{array}$ & $\begin{array}{c}2,130 \\
(1,484- \\
2,777)\end{array}$ & $\begin{array}{c}5.73 \\
(3.10-8.37)\end{array}$ & $\begin{array}{c}220 \\
(111-321)\end{array}$ & $\begin{array}{c}1,295 \\
(700-1,891)\end{array}$ & Combined & vith nature-fo & cused parks & $\begin{array}{c}585 \\
(439-730)\end{array}$ & $\begin{array}{c}3,426 \\
(2,572- \\
4,279)\end{array}$ \\
\hline
\end{tabular}


Table B4. Calculated Marginal and Total Values for All NPS Program Models

\begin{tabular}{|c|c|c|c|c|c|c|c|c|c|c|c|c|c|c|}
\hline & \multicolumn{3}{|c|}{$\begin{array}{c}\text { Historic sites and buildings } \\
\text { protected }\end{array}$} & \multicolumn{3}{|c|}{$\begin{array}{c}\text { Acres for recreation } \\
\text { transferred to communities } \\
\text { each year }\end{array}$} & \multicolumn{3}{|c|}{$\begin{array}{l}\text { Natural landmarks } \\
\text { protected each year }\end{array}$} & \multicolumn{3}{|c|}{$\begin{array}{l}\text { School children served by NPS } \\
\text { educational programs each year }\end{array}$} & \multicolumn{2}{|c|}{ All Programs } \\
\hline & $\frac{\text { Marg. }}{\text { Val. }}$ & \multicolumn{2}{|c|}{ Total Value } & \multirow{2}{*}{$\begin{array}{l}\text { Marg. } \\
\underline{\text { Val. }} \\
\text { \$/acre } \\
(95 \% \\
\text { C.I. })\end{array}$} & \multirow{2}{*}{\multicolumn{2}{|c|}{ 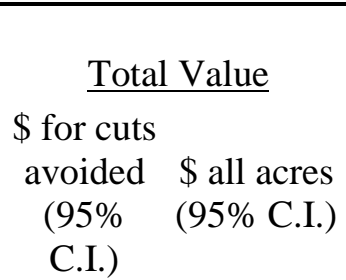 }} & \multirow{2}{*}{$\begin{array}{l}\text { Marg. } \\
\underline{\text { Val. }} \\
\text { \$/site } \\
(95 \% \\
\text { C.I. })\end{array}$} & \multicolumn{2}{|c|}{ Total Value } & \multirow{2}{*}{$\begin{array}{l}\text { Marg. Val. } \\
\text { \$/student } \\
\text { (95\% C.I.) }\end{array}$} & \multicolumn{2}{|c|}{ Total Value } & \multicolumn{2}{|c|}{ Total Value } \\
\hline & $\begin{array}{l}\$ / \text { site } \\
(95 \% \\
\text { C.I. })\end{array}$ & $\begin{array}{l}\text { \$ for cuts } \\
\text { avoided } \\
(95 \% \\
\text { C.I. })\end{array}$ & $\begin{array}{l}\text { \$ for all } \\
\text { sites } \\
(95 \% \\
\text { C.I. })\end{array}$ & & & & & $\begin{array}{l}\text { \$ for cuts } \\
\text { avoided } \\
(95 \% \\
\text { C.I. })\end{array}$ & $\begin{array}{l}\$ \text { all } \\
\text { sites } \\
(95 \% \\
\text { C.I. })\end{array}$ & & $\begin{array}{l}\text { \$ for cuts } \\
\text { avoided } \\
\text { (95\% } \\
\text { C.I. })\end{array}$ & $\begin{array}{l}\text { \$ all } \\
\text { stud. } \\
(95 \% \\
\text { C.I. })\end{array}$ & $\begin{array}{l}\$ \text { for cuts } \\
\text { avoided } \\
(95 \% \\
\text { C.I. })\end{array}$ & $\begin{array}{c}\text { \$all } \\
\text { programs } \\
(95 \% \\
\text { C.I. })\end{array}$ \\
\hline $\begin{array}{l}\text { 1. Base, no } \\
\text { weights }\end{array}$ & $\begin{array}{c}0.13 \\
(-0.03- \\
0.28)\end{array}$ & $\begin{array}{c}39 \\
(-8.14- \\
86)\end{array}$ & $\begin{array}{c}253 \\
(-53- \\
559)\end{array}$ & $\begin{array}{c}0.06 \\
(-0.04- \\
0.16)\end{array}$ & $\begin{array}{c}25 \\
(-18-68)\end{array}$ & $\begin{array}{c}162 \\
(-114-438)\end{array}$ & $\begin{array}{c}2.99 \\
(0.29- \\
5.68)\end{array}$ & $\begin{array}{c}54 \\
(5.30- \\
102)\end{array}$ & $\begin{array}{l}341 \\
(34- \\
648)\end{array}$ & $\begin{array}{c}1.99 \mathrm{e}^{-4} \\
\left(1.31 \mathrm{e}^{-4}-2.67 \mathrm{e}^{-}\right. \\
4)\end{array}$ & $\begin{array}{c}161 \\
(106-217)\end{array}$ & $\begin{array}{c}814 \\
(536- \\
1,093)\end{array}$ & $\begin{array}{c}279 \\
(250- \\
308)\end{array}$ & $\begin{array}{c}1,570 \\
(1,406- \\
1,734)\end{array}$ \\
\hline $\begin{array}{l}2 . \\
\text { Weighted } \\
\text { for demog. }\end{array}$ & $\begin{array}{c}0.32 \\
(0.13- \\
0.51)\end{array}$ & $\begin{array}{c}98 \\
(40-156)\end{array}$ & $\begin{array}{c}641 \\
(262- \\
1,020)\end{array}$ & $\begin{array}{c}0.04 \\
(-0.10- \\
0.18)\end{array}$ & $\begin{array}{c}17 \\
(-42-76)\end{array}$ & $\begin{array}{c}108 \\
(-275-491)\end{array}$ & $\begin{array}{c}1.79 \\
(-1.33- \\
4.92) \\
\end{array}$ & $\begin{array}{c}32 \\
(-24-89)\end{array}$ & $\begin{array}{c}204 \\
(-152- \\
561)\end{array}$ & $\begin{array}{c}1.66 \mathrm{e}^{-4} \\
\left(8.33 \mathrm{e}^{-5}-2.48 \mathrm{e}^{-}\right. \\
4)\end{array}$ & $\begin{array}{c}135 \\
(68-202)\end{array}$ & $\begin{array}{c}679 \\
(342- \\
1,017)\end{array}$ & $\begin{array}{c}282 \\
(245- \\
319)\end{array}$ & $\begin{array}{c}1,633 \\
(1,421- \\
1,845)\end{array}$ \\
\hline $\begin{array}{l}\text { 3. } \\
\text { Weighted } \\
\text { for Nat'l } \\
\text { Park visits }\end{array}$ & $\begin{array}{c}0.16 \\
(0.02- \\
0.29)\end{array}$ & $\begin{array}{c}48 \\
(7.47-89)\end{array}$ & $\begin{array}{c}316 \\
(49-584)\end{array}$ & $\begin{array}{c}0.04 \\
(-0.06- \\
0.13)\end{array}$ & $\begin{array}{c}15 \\
(-24-55)\end{array}$ & $\begin{array}{c}98 \\
(-157-354)\end{array}$ & $\begin{array}{c}3.05 \\
(0.71- \\
5.40)\end{array}$ & $\begin{array}{c}55 \\
(13-97)\end{array}$ & $\begin{array}{l}348 \\
(81- \\
615)\end{array}$ & $\begin{array}{c}1.67 \mathrm{e}^{-4} \\
\left(1.09 \mathrm{e}^{-4}-2.24 \mathrm{e}^{-}\right. \\
4)\end{array}$ & $\begin{array}{c}135 \\
(89-182)\end{array}$ & $\begin{array}{c}683 \\
(448- \\
918)\end{array}$ & $\begin{array}{c}254 \\
(227- \\
281)\end{array}$ & $\begin{array}{c}1,445 \\
(1,290- \\
1,601)\end{array}$ \\
\hline $\begin{array}{l}4 . \\
\text { Weighted } \\
\text { for demog. } \\
\text { \& Park } \\
\text { visits }\end{array}$ & $\begin{array}{c}0.33 \\
(0.14- \\
0.51)\end{array}$ & $\begin{array}{c}100 \\
(43-156)\end{array}$ & $\begin{array}{c}652 \\
(282- \\
1,021)\end{array}$ & $\begin{array}{c}0.04 \\
(-0.09- \\
0.18)\end{array}$ & $\begin{array}{c}17 \\
(-39-73)\end{array}$ & $\begin{array}{c}111 \\
(-253-475)\end{array}$ & $\begin{array}{c}2.09 \\
(-0.99- \\
5.18)\end{array}$ & $\begin{array}{c}38 \\
(-18-93)\end{array}$ & $\begin{array}{c}239 \\
(-113- \\
590)\end{array}$ & $\begin{array}{c}1.36 \mathrm{e}^{-4} \\
\left(5.32 \mathrm{e}^{-5}-2.19 \mathrm{e}^{-}\right. \\
4)\end{array}$ & $\begin{array}{c}111 \\
(43-178)\end{array}$ & $\begin{array}{c}559 \\
(218- \\
899)\end{array}$ & $\begin{array}{c}265 \\
(233- \\
298)\end{array}$ & $\begin{array}{c}1,560 \\
(1,372- \\
1,748)\end{array}$ \\
\hline $\begin{array}{l}\text { 5. Nat'l } \\
\text { Park } \\
\text { Visitors } \\
\text { only }\end{array}$ & $\begin{array}{c}0.05 \\
(-0.19- \\
0.28)\end{array}$ & $\begin{array}{c}15 \\
(-58-87)\end{array}$ & $\begin{array}{c}95 \\
(-376- \\
567)\end{array}$ & $\begin{array}{c}0.16 \\
(0.00- \\
0.32)\end{array}$ & $\begin{array}{c}68 \\
(0.78- \\
135)\end{array}$ & $\begin{array}{c}440 \\
(5.03-875)\end{array}$ & $\begin{array}{c}2.70 \\
(-1.59- \\
6.99)\end{array}$ & $\begin{array}{c}49 \\
(-29- \\
126)\end{array}$ & $\begin{array}{c}308 \\
(-182- \\
797)\end{array}$ & $\begin{array}{c}2.84 \mathrm{e}^{-4} \\
\left(1.71 \mathrm{e}^{-4}-3.97 \mathrm{e}^{-}\right. \\
4)\end{array}$ & $\begin{array}{c}231 \\
(139-323)\end{array}$ & $\begin{array}{l}1,165 \\
(703- \\
1,627)\end{array}$ & $\begin{array}{c}362 \\
(303- \\
421)\end{array}$ & $\begin{array}{l}2,008 \\
(1,691- \\
2,325)\end{array}$ \\
\hline $\begin{array}{l}\text { 6. Non- } \\
\text { visitors }\end{array}$ & $\begin{array}{c}0.19 \\
(0.002- \\
0.37)\end{array}$ & $\begin{array}{c}57 \\
(0.59- \\
114)\end{array}$ & $\begin{array}{c}374 \\
(3.85- \\
744)\end{array}$ & $\begin{array}{c}0.01 \\
(-0.11- \\
0.14)\end{array}$ & $\begin{array}{c}5.72 \\
(-46-57)\end{array}$ & $\begin{array}{c}37 \\
(-295-369)\end{array}$ & $\begin{array}{c}3.54 \\
(0.45- \\
6.63)\end{array}$ & $\begin{array}{c}64 \\
(8.03- \\
119)\end{array}$ & $\begin{array}{l}403 \\
(51- \\
756)\end{array}$ & $\begin{array}{c}7.84 \mathrm{e}^{-5} \\
\left(-1.35 \mathrm{e}^{-7}-\right. \\
\left.1.57 \mathrm{e}^{-4}\right)\end{array}$ & $\begin{array}{c}64 \\
(-0.10- \\
128)\end{array}$ & $\begin{array}{c}322 \\
(-0.50- \\
644)\end{array}$ & $\begin{array}{c}190 \\
(163- \\
218)\end{array}$ & $\begin{array}{l}1,136 \\
(968- \\
1,304)\end{array}$ \\
\hline
\end{tabular}




\section{Detailed Breakdown of Respondents' Reasons for Zero Bids}

Table C. Reasons for Zero Bids and Protest Responses

\begin{tabular}{|c|c|c|c|c|c|c|}
\hline \multirow{2}{*}{$\begin{array}{l}\text { National Parks } \\
\text { Reason for zero bid-not protest }\end{array}$} & \multicolumn{2}{|c|}{ Option A } & \multicolumn{2}{|c|}{ Option B } & \multicolumn{2}{|c|}{ Option C } \\
\hline & $\begin{array}{c}\% \text { of } \\
\text { sample }\end{array}$ & $\begin{array}{c}\text { \% selecting } \\
\text { option } A\end{array}$ & $\begin{array}{c}\text { \% of } \\
\text { sample }\end{array}$ & $\begin{array}{c}\text { \% selecting } \\
\text { option } B\end{array}$ & $\begin{array}{c}\% \text { of } \\
\text { sample }\end{array}$ & $\begin{array}{c}\text { \% selecting } \\
\text { option C }\end{array}$ \\
\hline $\begin{array}{l}\text { National Parks are not worth that much } \\
\text { to me. }\end{array}$ & $0.28 \%$ & $2.22 \%$ & $0.14 \%$ & $0.44 \%$ & $0.14 \%$ & $0.28 \%$ \\
\hline I can't afford to pay that much. & $1.41 \%$ & $11.11 \%$ & $0.28 \%$ & $0.88 \%$ & $0.56 \%$ & $1.14 \%$ \\
\hline $\begin{array}{l}\text { Only the people who use National Parks } \\
\text { should have to pay for them. }\end{array}$ & $1.27 \%$ & $10.00 \%$ & $0.00 \%$ & $0.00 \%$ & $0.00 \%$ & $0.00 \%$ \\
\hline Other - not protest & $0.42 \%$ & $3.33 \%$ & $0.00 \%$ & $0.00 \%$ & $0.00 \%$ & $0.00 \%$ \\
\hline \multicolumn{7}{|l|}{ Reason for zero bid-protest } \\
\hline $\begin{array}{l}\text { We need to cut all government spending } \\
\text { so we can reduce the federal deficit. }\end{array}$ & $2.68 \%$ & $21.11 \%$ & $0.71 \%$ & $2.21 \%$ & $0.28 \%$ & $0.57 \%$ \\
\hline Taxes are too high already. & $2.68 \%$ & $21.11 \%$ & $0.14 \%$ & $0.44 \%$ & $0.42 \%$ & $0.85 \%$ \\
\hline $\begin{array}{l}\text { National Parks should be paid for with } \\
\text { existing tax dollars. }\end{array}$ & $1.69 \%$ & $13.33 \%$ & $0.85 \%$ & $2.65 \%$ & $1.69 \%$ & $3.41 \%$ \\
\hline Other - protest & $0.42 \%$ & $3.33 \%$ & $0.28 \%$ & $0.88 \%$ & $0.56 \%$ & $1.14 \%$ \\
\hline Total protest for Parks & $7.49 \%$ & $58.89 \%$ & $1.98 \%$ & $6.19 \%$ & $2.97 \%$ & $5.97 \%$ \\
\hline NPS Programs & \multicolumn{2}{|c|}{ Option D } & \multicolumn{2}{|c|}{ Option E } & \multicolumn{2}{|c|}{ Option F } \\
\hline Reason for zero bid - not protest & $\begin{array}{c}\% \text { of } \\
\text { sample }\end{array}$ & $\begin{array}{l}\text { \% selecting } \\
\text { option } D\end{array}$ & $\begin{array}{c}\text { \% of } \\
\text { sample }\end{array}$ & $\begin{array}{l}\text { \% selecting } \\
\text { option } E\end{array}$ & $\begin{array}{c}\% \text { of } \\
\text { sample }\end{array}$ & $\begin{array}{c}\text { \% selecting } \\
\text { option } F\end{array}$ \\
\hline $\begin{array}{l}\text { NPS programs are not worth that much } \\
\text { to me. }\end{array}$ & $0.28 \%$ & $1.72 \%$ & $0.00 \%$ & $0.00 \%$ & $0.00 \%$ & $0.00 \%$ \\
\hline I can't afford to pay that much. & $2.54 \%$ & $15.52 \%$ & $0.85 \%$ & $1.86 \%$ & $0.71 \%$ & $2.25 \%$ \\
\hline $\begin{array}{l}\text { Only the people who use NPS programs } \\
\text { should have to pay for them. }\end{array}$ & $1.55 \%$ & $9.48 \%$ & $0.00 \%$ & $0.00 \%$ & $0.00 \%$ & $0.00 \%$ \\
\hline Other - not protest & $0.42 \%$ & $2.59 \%$ & $0.00 \%$ & $0.00 \%$ & $0.71 \%$ & $2.25 \%$ \\
\hline \multicolumn{7}{|l|}{ Reason for zero bid-protest } \\
\hline $\begin{array}{l}\text { We need to cut all government spending } \\
\text { so we can reduce the federal deficit. }\end{array}$ & $2.97 \%$ & $18.10 \%$ & $0.85 \%$ & $1.86 \%$ & $0.42 \%$ & $1.35 \%$ \\
\hline Taxes are too high already. & $2.68 \%$ & $16.38 \%$ & $0.71 \%$ & $1.55 \%$ & $0.28 \%$ & $0.90 \%$ \\
\hline $\begin{array}{l}\text { NPS programs should be paid for with } \\
\text { existing tax dollars. }\end{array}$ & $2.68 \%$ & $16.38 \%$ & $1.13 \%$ & $2.48 \%$ & $0.99 \%$ & $3.15 \%$ \\
\hline Other - protest & $0.85 \%$ & $5.17 \%$ & $0.42 \%$ & $0.93 \%$ & $0.85 \%$ & $2.70 \%$ \\
\hline Total protest for Programs & $9.18 \%$ & $56.03 \%$ & $3.11 \%$ & $6.83 \%$ & $2.54 \%$ & $8.11 \%$ \\
\hline
\end{tabular}

